\title{
Prevalence of specific and recurrent/founder pathogenic variants in BRCA genes in breast and ovarian cancer in North Africa
}

Oubaida ElBiad ${ }^{1,2,3^{*}}$, Abdelilah Laraqui ${ }^{1,2,4}$, Fatima El Boukhrissi ${ }^{5}$, Chaimaa Mounjid ${ }^{1}$, Maryame Lamsisi ${ }^{6}$, Tahar Bajjou', Hicham Elannaz ${ }^{2,4}$, Amine Idriss Lahlou ${ }^{2,4}$, Jaouad Kouach7, Khadija Benchekroune ${ }^{7}$, Mohammed Oukabli ${ }^{8}$, Hafsa Chahdi ${ }^{8}$, Moulay Mustapha Ennaji ${ }^{6}$, Rachid Tanz ${ }^{9}$, Yassir Sbitti ${ }^{9}$, Mohammed Ichou ${ }^{9}$, Khalid Ennibi ${ }^{2,4}$, Bouabid Badaoui $^{3}$ and Yassine Sekhsokh ${ }^{1}$

\begin{abstract}
Background: Elucidation of specific and recurrent/founder pathogenic variants (PVs) in BRCA (BRCA1 and BRCA2) genes can make the genetic testing, for breast cancer (BC) and/or ovarian cancer (OC), affordable for developing nations.

Methods: To establish the knowledge about BRCA PVs and to determine the prevalence of the specific and recurrent/founder variants in BRCA genes in $B C$ and/or OC women in North Africa, a systematic review was conducted in Morocco, Algeria, and Tunisia.
\end{abstract}

Results: Search of the databases yielded 25 relevant references, including eleven studies in Morocco, five in Algeria, and nine in Tunisia. Overall, 15 studies investigated both BRCA1 and BRCA2 genes, four studies examined the entire coding region of the $B R C A 1$ gene, and six studies in which the analysis was limited to a few $B R C A 1$ and/or $B R C A 2$ exons. Overall, 76 PVs (44 in BRCA1 and32 in BRCA2) were identified in $196 \mathrm{BC}$ and/or OC patients (129 BRCA1 and 67 BRCA2 carriers). Eighteen of the 76 (23.7\%) PVs [10/44 (22.7\%) in BRCA1 and 8/32 (25\%) in BRCA2] were reported for the first time and considered to be novel PVs. Among those identified as unlikely to be of North African origin, the BRCA1 c.68_69del and BRCA1 c.5266dupC Jewish founder alleles and PVs that have been reported as recurrent/founder variants in European populations (ex: BRCA1 c.181T >G, BRCA1 c1016dupA). The most well characterized PVs are four in BRCA1 gene [c.211 dupA (14.7\%), c.798_799detTT (14\%), c.5266dup (8.5\%), c.5309G>T (7.8\%), c.3279delC (4.7\%)] and one in BRCA2 [c.1310_1313detAAGA (38.9\%)]. The c.211dupA and c.5309G>T PVs were identified as specific founder variants in Tunisia and Morocco, accounting for 35.2\% (19/54) and 20.4\% (10/49) of total established BRCA1 PVs, respectively. c.798_799delTT variant was identified in 14\% (18/129) of all BRCA1 North African carriers, suggesting a founder allele. A broad spectrum of recurrent variants including BRCA1 3279delC, BRCA1 C.5266dup and BRCA2 c.1310_1313detAAGA was detected in 42 patients. BRCA1 founder variants explain around $36.4 \%(47 / 129)$ of BC and outnumber $B R C A 2$ founder variants by a ratio of $\approx 3: 1$.

Conclusions: Testing BC and/or OC patients for the panel of specific and recurrent/founder PVs might be the most cost-effective molecular diagnosis strategy.

\footnotetext{
*Correspondence: obdo90@gmail.com

${ }^{3}$ Laboratoire de Biodiversité, Ecologie et Génome, Faculté des Sciences,

Université Mohammed V, Rabat, Maroc

Full list of author information is available at the end of the article
} original author(s) and the source, provide a link to the Creative Commons licence, and indicate if changes were made. The images or other third party material in this article are included in the article's Creative Commons licence, unless indicated otherwise in a credit line to the material. If material is not included in the article's Creative Commons licence and your intended use is not permitted by statutory regulation or exceeds the permitted use, you will need to obtain permission directly from the copyright holder. To view a copy of this licence, visit http://creativecommons.org/licenses/by/4.0/. The Creative Commons Public Domain Dedication waiver (http://creativeco mmons.org/publicdomain/zero/1.0/) applies to the data made available in this article, unless otherwise stated in a credit line to the data. 
Keywords: BRCA genes, Specific variant, recurrent/founder variant, North Africa

\section{Introduction}

Breast cancer (BC) became the most common cancer globally as of 2021, with an estimated 2.3 million new cases, representing $11.7 \%$ of all cancer cases [1]. According to the GLOBOCAN Cancer Tomorrow prediction tool, incident cases are expected to increase by more than $46 \%$ by 2040 . The increasing global BC burden is mainly observed in low- and middle-income countries, particularly women under the age of fifty [2]. The rapid changes in diets and lifestyles, and social-cultural environments brought about by growing economies have had an impact on the prevalence of factors associated with increased BC risk. Therefore, the increase in the proportion of women in the industrial work force gave rise to a postponed pregnancy, having fewer children and, excessive total and abdominal body fat and physical inactivity which resulted in a convergence toward the risk factor profile of countries in Western Europe and narrowing international gaps in BC morbidity [1].

$\mathrm{BC}$ incidence rates increased uniformly and rapidly in transitioning countries. Some of the most rapid increases are occurring in North Africa, including Morocco, Algeria, Tunisia, Libya, and Mauritania. The incidence of BC among North African women aged 15 to 49 is lower than that in Western countries. However, the young age pyramid of North Africa makes the relative proportion of $\mathrm{BC}$ in young patients substantially higher than that in Western countries (e.g.50 to $60 \%$ versus $20 \%$ in France) [3]. The size and grade of breast tumors in North Africa is higher and the median age of onset (48) is more than ten years younger than the European/North American median of 61 [4], and is often diagnosed in premenopausal women. The relative frequency of triple-negative and inflammatory $\mathrm{BC}$ is also higher [3]. The combination of lower incidence and lower age of onset of $\mathrm{BC}$ in North Africa suggests that genetic factors such as germline pathogenic variants (PVs) in BRCA (BRCA1 and $B R C A 2)$ genes may contribute to a larger proportion of $\mathrm{BC}$ overall.

Prevalence and PVs distribution of $B R C A$ genes can vary in different regions and among different ethnic groups due to specific and recurrent/founder variants. Founder variants originated from an ancestor population and maintained over time, were observed in specific geographic areas [5]. Significant evidence from founder mutation has been described in Ashkenazi Jewish, Icelandic, French-Canadian, Brazilian and Italian populations [5]. Traditionally, well-documented founder BRCA $\mathrm{PVs}$ have been instrumental to informed prioritization strategies for time- and cost-effective genetic testing and prompt identification of carrier individuals [6]. Given the high rates of consanguinity and endogamy marriage culture among the North African populations, it seems plausible that specific and recurrent/founder BRCA PVs may be detected in the region. Rebbeck et al. investigated 1650 and 1731 unique PVs in BRCA1 and BRCA2 genes, respectively, from 29,700 families worldwide and observed distinct variation in PV type or prevalence by geographical region and race/ethnicity [7]. Racial and ethnic differences can play an important role in hereditary breast carcinomas through its associations with specific and recurrent/founder variants. The purpose of this review is to establish the knowledge about $B R C A$ PVs and to determine the prevalence of the specific and recurrent/founder variants in $B R C A$ genes in $\mathrm{BC}$ and/or $\mathrm{OC}$ women in Morocco, Algeria and Tunisia. It seems that no surveys on BRCA PVs have yet been conducted in Libya and Mauritania, therefore no data are available.

\section{Methods}

We conducted a systematic review of all the literature published on the BRCA PVs spectrum and the frequencies in BC women in North Africa. Pub Med, Science Direct and Google Scholar were searched up to June 2021 for eligible studies using the following keywords: "breast cancer", or "breast tumor", or "adenocarcinoma of the breast", or "BRCA genes", or "BRCA1 gene", or "BRCA2 gene", or "BRCA pathogenic variant", or "BRCA mutation", or "BRCA prevalence" or "BRCA frequency", or "BRCA rate" or "BRCA incidence". An additional literature search was also conducted using North Africa and specific country names belonging to the considered region and any other variant names for any of North Africa countries (ex: Mediterranean countries, Maghreb, Arab population). We manually checked reference lists of the included studies and relevant reviews to identify additional studies. We also searched relevant abstracts reported in the most important multi-disciplinary societies of medical oncology such as the American Society of Clinical Oncology (ASCO) meetings to identify unpublished studies.

Original research articles were identified from Morocco, Algeria, and Tunisia. The included studies had to meet the following criteria: the study must relate to the role of $B R C A 1$ and/or BRCA2 genes in $\mathrm{BC}$ and/or OC, it should also analyze all the coding regions, test for known mutations, or select exons of $B R C A$ genes. Besides, the study must provide sufficient information on the $B R C A 1$ 
Table 1 Details of studies examining BRCA1 and BRCA2 genes in North Africa

\begin{tabular}{|c|c|c|c|c|c|}
\hline & $\begin{array}{l}\text { Number of } \\
\text { patients }\end{array}$ & $\begin{array}{l}\text { BRCA } \\
\text { carriers }\end{array}$ & Mean age & Methods & Covered gene region \\
\hline \multicolumn{6}{|l|}{ Morocco } \\
\hline Laarabi et al. (2011) [8] & 8 & 6 & NA & Direct sequencing & All \\
\hline Tazzite et al. (2012) [9] & 40 & 10 & 38 & Direct sequencing & All \\
\hline Laraqui et al. (2013) [10] & 121 & 7 & 44 & Direct sequencing & BRCA1 \\
\hline Elkhachibi et al. (2015) [11] & 71 & 2 & 41 & HRM, Direct sequencing & Exon11(BRCA1) \\
\hline Jouali et al. (2016) [12] & 15 & 6 & 47 & NGS & All \\
\hline Quiles et al. (2016) [13] & 11 & 8 & 36.5 & Direct sequencing & Exon20 (BRCA1) \\
\hline Laarabi et al. (2017) [14] & 122 & 14 & & $\begin{array}{l}\text { Direct sequencing ( } 51 \text { patients), NGS ( } 23 \text { patients), } \\
\text { Target screening (BRCA2 exon 10,48 patients) }\end{array}$ & All, Exon10 (BRCA2) \\
\hline El Ansari et al. (2020) [15] & 64 & 18 & 42 & NGS & All \\
\hline Bakkach et al. (2020) [16] & 33 & 4 & 35 & NGS & All \\
\hline Mansouri et al (2020) [17] & 32 & 7 & 45 & NGS & All \\
\hline Jouali et al. (2020) [18] & 39 & 1 & 46 & NGS & All \\
\hline \multicolumn{6}{|l|}{ Algeria } \\
\hline Uhrhammeret al. (2008) [19] & 51 & 5 & 31.5 & Direct sequencing, MLPA & $B R C A 1$ \\
\hline Cherbal et al. (2010) [20] & 86 & 10 & NA & Direct sequencing, MLPA & All \\
\hline Henouda et al. (2016) [21] & 40 & 8 & 36.6 & Direct sequencing, MLPA & All \\
\hline Boulenouar et al. (2018) [22] & 50 & 4 & NA & Direct sequencing, MLPA & All \\
\hline Mehemmai et al. (2019) [23] & 113 & 7 & 44 & Direct sequencing, NGS & $\begin{array}{l}\text { Exon3, 4, and } 10 \\
(B R C A 1) \text {, Exon } 10 \\
(B R C A 2)\end{array}$ \\
\hline \multicolumn{6}{|l|}{ Tunisia } \\
\hline Troudi et al. (2007) [24] & 36 & 7 & 56.8 & Direct sequencing & All \\
\hline Troudi et al. (2008) [25] & 32 & 5 & 46.5 & Direct sequencing & BRCA1 \\
\hline Mahfoudh et al. (2011) [26] & 24 & 6 & 41 & Direct sequencing & BRCA1 \\
\hline Riahi et al. (2013) [27] & 48 & 12 & NA & Direct sequencing & All \\
\hline Fourati et al. (2014) [28] & 66 & 12 & 45 & Direct sequencing & $\begin{array}{l}\text { BRCA1 }(5,20, \text { and } \\
\text { part of } 11), \\
\operatorname{BRCA2}(10,11)\end{array}$ \\
\hline Msolly et al. (2015) [29] & 17 & 1 & 45.8 & Direct sequencing & All \\
\hline Mahfoudh et al. (2019) [30] & 33 & 2 & 53.8 & Direct sequencing & All \\
\hline Mighri et al. (2020) [31] & 112 & 9 & NA & Direct sequencing, NGS & All \\
\hline Guerfali et al. (2021) [32] & 134 & 19 & NA & NGS & All \\
\hline
\end{tabular}

HRM: High Resolution Melt, MLPA: Multiplex Ligation-dependent Probe Amplification, NGS: Next generation sequencing, NA: not available

and/or BRCA2 PV frequencies. Likely pathogenic variants or variants of unknown/uncertain significance (VUS) were excluded from this study. The prevalence of any variant was included regardless of whether the variant was specific or recurrent/founder. Also, where study authors did not clearly state that variant was germline or somatic and/or pathogenic, or clinically relevant, the variant was classified as not reported/unclear in order to avoid any misinterpretation. Details of the study methods, population characteristics, and prevalence of $B R C A$ PVs were extracted and summarized in Table 1.

A reinterpretation of sequence variants was conducted by following the classification system recommended by the American College of Medical Genetics and Genomics-Association for Molecular Pathology (ACMG-AMP) Standards and Guideline for the Interpretation of Sequence Variants [33]. The 2015 ACMGAMP guidelines were a major step toward establishing a common framework for variant classification. The ACMG-AMP suggests that the clinical pathogenicity of a variant can be evaluated using multiple lines of evidence from available literature, structural/functional data, population frequencies, and statistical analyses of clinical data. The process can result in 1 of 5 classifications: benign (class 1 ), likely benign (2), VUS (class 3 ), likely pathogenic (class 4), and pathogenic (class 5). 
Variants were considered to be "founder" if they were described as such in the primary literature, based on confirmatory haplotype analysis or population frequency.

\section{Results}

The search of the databases yielded 25 relevant references which are closely related to defining the inclusion criteria and was included in this review. The retrieved articles describe studies conducted in Morocco $(n=11)$ [8-18], Algeria $(\mathrm{n}=5)$ [19-23], and Tunisia $(\mathrm{n}=9)$ [24-32]. Overall, 15 studies investigated both BRCA1 and BRCA2 genes $[8,9,12,15-18,20-22,25-27,29,31,32]$, four studies examined the entire coding regions of the BRCA1 gene $[10,19,24,30]$, and six studies in which the analysis was restricted to a few $B R C A 1$ and/or BRCA2 exons [11, 13, 14, 23, 28].

Overall, we observed 76 distinct $B R C A$ PVs (44 in $B R C A 1$ and 32 in $B R C A 2$ ). The identified variants are found in $196 \mathrm{BC}$ and/or OC patients (129 BRCA1 carriers and $67 B R C A 2$ carriers). A total of 18 of the 76 (23.7\%) PVs [10/44 (22.7\%) in BRCA1, 8/32 (25\%) in $B R C A 2]$ were reported for the first time and were considered to be novel PVs in the North African populations. Among them, four PVs were reported in Morocco (c.3453delT in BRCA1 [12], and c.3381delT, c.7110delA, c.7234_7235insG in BRCA2 [9], three in Algeria (deletion of exon2 in BRCA1 [20], c.2805delAand c.6450del in BRCA2 [21], and eleven in Tunisia (c.211dupA [24, 25], c.296_297delTG [32], c.2418dupA [31], c.3254delG [32], c.3364_3370dupACAGATT [32], c.3751dup [28], c.4067_4071delAAGAA in BRCA1 [32] and c.1313dupT [27], c.1976_1800delCTTAT [27], c.2095 C >T [32], c.7654dupT [27] in BRCA2). The reported PVs in BRCA genes from North African studies are presented in Table 2.

Among those identified PVs, some are unlikely to be of North African origin which includes the BRCA1 c.68_69del and BRCA1 c.5266dupC Jewish founder variants, as well as PVs that have been reported as founder variants in European populations (ex: BRCA1 c.181T>G in Poland). Furthermore, other PVs have been described worldwide and represented as common PVs in several populations (ex: BRCA1 c.1016dupA in Italy, Germany, Scandinavian countries and French-Canadians, $B R C A 1$ c. $2125 \_2126$ ins A in French-Canadians, BRCA1 c. $2338 \mathrm{C}>\mathrm{T}$ and $B R C A 2$ c.1813dupA in Germany, BRCA1 c.5030_5033delCTAA in France, BRCA2 c.3860delA in Austrian population, and BRCA2 c.3847_3848delGT in Denmark).

The most well characterized five PVs are four in BRCA1 gene including c.211dupA $(14.7 \%, 19 / 129)$ [24, $25,27,28,31]$, c.798_799detTT $(14 \%, 18 / 129)$ [9, 10, $15-18,20,24,29,30]$, c.5266dup $(8.5 \%, 11 / 129)$ [24-28,
30], c.5309G $>\mathrm{T}(7.8 \%, 10 / 129) \quad[13,17], \quad$ c.3279delC $(4.7 \%, 6 / 129)[9,11,15]$ and one in BRCA2 including c.1310_1313detAAGA $(38.9 \%, 26 / 67)$ [12, 14, 20, 28, 32]. The BRCA1 c.798_799delTT was identified in 18 North African patients, accounting for $14 \%(18 / 129)$ of the total identified BRCA1 PVs [9, 10, 15-20, 24, 29, 30]. Microsatellite markers in and flanking the $B R C A 1$ locus showed a common haplotype in Algerian and Tunisian c.798_799delTT carriers, suggesting the first non-Jewish founder variant to be described in Northern Africa [19]. The c.798_799delTT variant, located in exon 11, is a frame-shift variant including two small deletions, two bases (TT) deletion, that cause truncated protein signal at codon 285 .

The other frequently recurrent PVs c.211dupA [24, $25,27,28,31]$ and c.5266dupC [24-28, 30] were found in 55.6\% (30/54) of BRCA1-related hereditary breast and ovarian cancer (HBOC) in Tunisian families but neither in Algerian nor in Moroccan families with $\mathrm{BC}$ and/or OC. The c.211dupA variant seems to be the most frequent BRCA PVs in Tunisia, accounting for 35.2\% (19/54) of all identified BRCA1 PVs [24, 25, 27, 28, 31]. It seems to be specific to Tunisia since it has never been previously described in any other population. The haplotype analysis supported the founder effect of c.211dupA in Tunisia and showed its recent origin. The frameshift variant c.211dupA results in a premature protein termination at codon 79 at the level of the splicing donor site of exon 5.

The c.5266dupC variant in BRCA1 exon 20 was detected in most Tunisian series, accounting for $20.4 \%$ $(11 / 54)$ of all BRCA1 PVs [24-27, 30]. This alteration is one of three well-characterized Ashkenazi Jewish founder mutations, with an overall carrier frequency of nearly $0.5 \%$ in this population. The c.5266dupC variant is the most globally frequent, pathogenic $B R C A 1$ variant and has been reported in varied populations in Africa, America, Asia and Europe. The haplotype analysis indicates the likelihood of a single founder origin both in Europe and in North America for the c.5266dupC variant [34]. Haplotype analysis may be useful in establishing whether or not it has a common founder origin for all BRCA1 c.5266dup variant in Tunisia. The BRCA1 c.5266dupC PV, located in coding exon 18, results from a duplication of $\mathrm{C}$ at nucleotide position 5266 , causing a translational frameshift with a predicted alternate stop codon.

The $B R C A 1$ c.5309G $>\mathrm{T}$ variant was identified in ten patients of which nine of which were $\mathrm{BC}$ and one was OC. Two of the $\mathrm{BC}$ patients were sporadic cases [13, 17]. A haplotype linked to c.5309G $>\mathrm{T}$, constructed from five microsatellite markers and spanning $1.54 \mathrm{Mb}$, was defined in one family. The alleles found in the other 
Table 2 Pathogenic BRCA1 and BRCA2 variants identified in North African breast/ovarian cancer patients

\begin{tabular}{|c|c|c|c|c|c|c|c|c|}
\hline & Exon & Mutation type & $\begin{array}{l}\text { Protein } \\
\text { consequence }\end{array}$ & $\begin{array}{l}\text { Number } \\
\text { of cases }\end{array}$ & Country & $\begin{array}{l}\text { Cancer } \\
\text { site }\end{array}$ & $\begin{array}{l}\text { Familial } \\
\text { Sporadic }\end{array}$ & References \\
\hline \multicolumn{9}{|c|}{ BRCA1 Pathogenic variants } \\
\hline c.46_74del29 & 2 & FS & p.Asn16fs & 2 & Algeria & $\mathrm{BC}$ & $\begin{array}{l}1 \text { Familial } \\
1 \text { Sporadic }\end{array}$ & [19] \\
\hline c.66_67delAG & 2 & FS & p.Glu23fs & 2 & Morocco & $B C$ & Familial & {$[15]$} \\
\hline c.68_69delAG & 2 & FS & p.Glu23fs & 4 & Morocco & $3 B C, 1 O C$ & Familial & {$[8]$} \\
\hline Del exon 2 & 2 & LGR & - & 2 & Algeria & $1 \mathrm{BOC}, \mathrm{BC}$ & Familial & {$[20,21]$} \\
\hline c.83_84delTG & 3 & FS & p.Arg28fs & 2 & Algeria & $\mathrm{BC}$ & $\begin{array}{l}1 \text { Familial } \\
1 \text { Sporadic }\end{array}$ & {$[19,20]$} \\
\hline c. $116 \mathrm{G}>\mathrm{A}$ & 3 & MS & p.Cys39Tyr & 1 & Morocco & $B C$ & Familial & {$[17]$} \\
\hline c. $181 \mathrm{~T}>\mathrm{G}$ & 5 & MS & p.Cys61Gly & 3 & $\begin{array}{l}\text { Morocco, } \\
\text { Algeria }\end{array}$ & $B C$ & Familial & {$[12,33]$} \\
\hline c.211dupA & 5 & FS & p.Arg71fs & 19 & Tunisia & $3 \mathrm{BC}, 2 \mathrm{BOC}$ & Familial & {$[24,25,27,28,31]$} \\
\hline c.212+2insG & 5 & Splicing & - & 1 & Tunisia & $\mathrm{BC}$ & Familial & {$[26]$} \\
\hline Del exon 8 & 8 & LGR & - & 1 & Algeria & $B C$ & Familial & {$[20]$} \\
\hline c. $2338 C>T$ & 10 & NS & p.GIn780Ter & 2 & Tunisia & OC & $\begin{array}{l}1 \text { Familial } \\
1 \text { Sporadic }\end{array}$ & [32] \\
\hline c.798_799delTT & 11 & FS & $\begin{array}{l}\text { p.Ser267Lys- } \\
\text { fsX19 }\end{array}$ & 18 & $\begin{array}{l}\text { Morocco, Alge- } \\
\text { ria, Tunisia }\end{array}$ & $B C$ & $\begin{array}{l}16 \text { Familial } \\
2 \text { Sporadic }\end{array}$ & $\begin{array}{l}{[9,10,15-20} \\
26,29]\end{array}$ \\
\hline c.1016dupA & 11 & FS & p.Val340LysfsX6 & 3 & Morocco & $\mathrm{BC}$ & Familial & {$[10,15]$} \\
\hline c.1504_1508delTTAAA & 11 & FS & p.Leu502fs & 1 & Tunisia & $B C$ & Familial & {$[27]$} \\
\hline c.1817delC & 11 & FS & p Pro606Leufs6 & 2 & Algeria & $B C$ & $\begin{array}{l}1 \text { Familial } \\
1 \text { Sporadic }\end{array}$ & {$[19,21]$} \\
\hline$c .202+1 G>A$ & 11 & FS & - & 1 & Algeria & $B C$ & Familial & [19] \\
\hline c.296_297delTG & 11 & FS & p.V99fs*9 & 1 & Tunisia & $B C$ & Familial & {$[32]$} \\
\hline c.2125_2126insA & 11 & FS & p.Phe709Tyrfs & 4 & $\begin{array}{l}\text { Morocco, } \\
\text { Algeria }\end{array}$ & $\mathrm{BC}$ & $\begin{array}{l}3 \text { Familials } \\
1 \text { Sporadic }\end{array}$ & {$[12,16,17,22]$} \\
\hline c.2418dupA & 11 & MS & p.Ala807Serfs & 1 & Tunisia & $B C$ & Familial & {$[31]$} \\
\hline c.2551delG & 11 & FS & p.Glu851fs & 2 & Tunisia & $B C$ & Familial & {$[24,25]$} \\
\hline c.2745dupT & 11 & NS & p.Ser915fs & 1 & Algeria & $\mathrm{BC}$ & Sporadic & [19] \\
\hline c.2805delA & 11 & FS & p.Asp936llefs & 2 & Morocco & $B C$ & Familial & {$[9,11]$} \\
\hline c.3254delG & 11 & FS & p.Arg1085Asnfs2 & 1 & Tunisia & $B C$ & Familial & {$[32]$} \\
\hline c.3279delC & 11 & FS & p.Tyr1094llefs & 6 & Morocco & $\mathrm{BC}$ & Familial & {$[9,11,15]$} \\
\hline c.3331_3334delCAAG & 11 & FS & p.Gln1111fs & 1 & Tunisia & $B C$ & Familial & {$[26]$} \\
\hline $\begin{array}{l}\text { c.3364_3370dupACA } \\
\text { GATT }\end{array}$ & 11 & FS & Stop1115 & 1 & Tunisia & $\mathrm{BC}$ & Familial & [32] \\
\hline c.3453delT & 11 & FS & p.Asp1151Glufs & 1 & Morocco & $\mathrm{BC}$ & Familial & {$[12]$} \\
\hline c.3715delT & 11 & FS & p.Ser1239fs & 1 & Algeria & $\mathrm{BC}$ & Sporadic & [19] \\
\hline c.3751dup & 11 & FS & p.Thr1251fs & 1 & Tunisia & OC & Familial & {$[28]$} \\
\hline c.4041_4042delAG & 11 & FS & p.Gly1348fs & 4 & Tunisia & $\begin{array}{l}1 \mathrm{BC}, 2 \mathrm{BOC} \\
1 \mathrm{MBC}\end{array}$ & Familial & {$[24,25,28,32]$} \\
\hline c.4065_4068del & 11 & FS & $\begin{array}{l}\text { p.Asn- } \\
1355 \text { Lysfs } 10\end{array}$ & 1 & Algeria & $\mathrm{BC}$ & Familial & {$[21]$} \\
\hline c.4067_4071delAAGAA & 11 & FS & p.GLn1356Argfs 8 & 1 & Tunisia & $\mathrm{BC}$ & Familial & {$[32]$} \\
\hline$C .5095 C>T$ & 14 & MS & p. Arg1699Trp & 2 & Morocco & $\mathrm{BC}$ & Familial & [10] \\
\hline $\begin{array}{l}\text { c.4676- ?_-4986 + ? } \\
\text { Del/p.? }\end{array}$ & 15 & $?$ & - & 2 & Algeria & $1 \mathrm{BOC}, 1 \mathrm{BC}$ & Familial & [23] \\
\hline c.5030_5033delCTAA & 15 & NS & p.Thr1677llefs2 & 3 & Tunisia & $1 \mathrm{BOC}, 2 \mathrm{OC}$ & Familial & {$[32]$} \\
\hline$c .4823 C>G$ & 16 & NS & p.Ser1608Ter & 1 & Morocco & $\mathrm{BC}$ & Familial & [15] \\
\hline C. $4942 A>T$ & 16 & NS & p.Lys1648X & 1 & Morocco & $B C$ & Sporadic & [10] \\
\hline c.5062_5064delGTT & 17 & FS & p.Val1688del & 1 & Morocco & $B C$ & Familial & {$[9]$} \\
\hline$c .5117 \mathrm{G}>\mathrm{C}$ & 18 & MS & p.Gly1706Ala & 1 & Algeria & $\mathrm{BC}$ & Familial & [22] \\
\hline
\end{tabular}


Table 2 (continued)

\begin{tabular}{|c|c|c|c|c|c|c|c|c|}
\hline & Exon & Mutation type & $\begin{array}{l}\text { Protein } \\
\text { consequence }\end{array}$ & $\begin{array}{l}\text { Number } \\
\text { of cases }\end{array}$ & Country & $\begin{array}{l}\text { Cancer } \\
\text { site }\end{array}$ & $\begin{array}{l}\text { Familial } \\
\text { Sporadic }\end{array}$ & References \\
\hline c.5158C>T & 18 & MS & p.Arg1720Trp & 1 & Morocco & $B C$ & Familial & [15] \\
\hline c.5266dupC & 20 & FS & p.Gln1756Profs & 11 & Tunisia & $9 \mathrm{BC}, 2 \mathrm{BOC}$ & Familial & {$[24-28,30]$} \\
\hline c.5309G $>\mathrm{T}$ & 20 & MS & p.Gly1770Val & 10 & Morocco & $9 B C, 1 O C$ & $\begin{array}{l}8 \text { Familial } \\
2 \text { Sporadic }\end{array}$ & {$[13,17]$} \\
\hline c. $5332+1 G>A$ & 20 & Splicing & - & 2 & Algeria & $1 \mathrm{BC}, 1 \mathrm{OC}$ & Familial & {$[21,23]$} \\
\hline C. $5390 C>A$ & 22 & NS & p.Ser1797Ter & 1 & Morocco & $\mathrm{BC}$ & Familial & {$[17]$} \\
\hline \multicolumn{9}{|c|}{$B R C A 2$ Pathogenic variants } \\
\hline c.17_20delAAGA & 2 & FS & p.Lys6Argfs 17 & 2 & Tunisia & $\mathrm{BC}$ & Familial & [32] \\
\hline$c .250 C>T$ & 3 & NS & p.GIn84Ter & 1 & Algeria & $B C$ & Familial & [32] \\
\hline$c .289 \mathrm{G}>\mathrm{T}$ & 3 & NS & p.Glu97Ter & 1 & Morocco & $B C$ & Familial & [22] \\
\hline C.517_1G>A & Intron 6 & SA & - & 1 & Morocco & $B C$ & Sporadic & {$[9]$} \\
\hline c.632_1G>A & 7 & Splicing & - & 2 & Tunisia & $B C$ & Familial & {$[32]$} \\
\hline c.1302_1305delAAGA & 10 & FS & p.Lys437fs & 1 & Morocco & OC & Familial & {$[15]$} \\
\hline c.1309del4 & 10 & FS & Stop459 & 1 & Tunisia & $\mathrm{BC}$ & Familial & {$[24]$} \\
\hline c.1310_1313delAAGA & 10 & FS & p.Lys437llefsX22 & 26 & $\begin{array}{l}\text { Morocco, Alge- } \\
\text { ria, Tunisia }\end{array}$ & $25 \mathrm{BC}, 1 \mathrm{MBC}$ & Familial & {$[12,14,20,28,31]$} \\
\hline c.1313dupT & 10 & FS & Stop451 & 2 & Tunisia & $\mathrm{BC}$ & Familial & {$[27]$} \\
\hline c.1528G >T & 10 & NS & p.Glu510 & 1 & Algeria & $B C$ & Familial & [21] \\
\hline c.1813dupA & 10 & FS & p. Ile605Asnfs 11 & 1 & Algeria & $B C$ & Familial & [23] \\
\hline c.1976_1800delCTTAT & 10 & FS & p.Ser599 & 1 & Tunisia & $B C$ & Familial & {$[32]$} \\
\hline$c .2095 C>T$ & 10 & NS & p.Gln699Ter & 1 & Tunisia & $B C$ & Familial & {$[32]$} \\
\hline c.5116_5119delAATA & 11 & FS & p.Arg2108Cys & 2 & Morocco & $B C$ & Familial & {$[16,17]$} \\
\hline c.3381delT & 11 & FS & p.Phe1127Leufs & 1 & Morocco & $B C$ & Familial & [16] \\
\hline c.3847_3848delGT & 11 & FS & p.Val1283fs & 1 & Morocco & OC & Familial & {$[9]$} \\
\hline c.3860delA & 11 & FS & p.Asn1287fs & 1 & Morocco & $\mathrm{BOC}$ & familial & [15] \\
\hline c.5073dupA & 11 & FS & p.Trp1692Metfs & 2 & Morocco & $\mathrm{BC}$ & Familial & {$[8]$} \\
\hline c.5576_5579delTTAA & 11 & FS & p.11859fs & 1 & Morocco & OC & familial & {$[15]$} \\
\hline c.5682insA & 11 & FS & - & 1 & Tunisia & $B C$ & familial & [24] \\
\hline c.5722_5723delCT & 11 & FS & p.Leu1908Argfs2 & 1 & Algeria & $B C$ & familial & {$[20]$} \\
\hline c.6450del & 11 & FS & $\begin{array}{l}\text { p.Val- } \\
\text { 2151Phefs17 }\end{array}$ & 1 & Algeria & $B C$ & familial & [21] \\
\hline c.7110delA & 14 & FS & p.Lys2370Asnfs & 2 & Morocco & $1 \mathrm{OC}, 1 \mathrm{BC}$ & familial & {$[9,15]$} \\
\hline c.7234_7235insG & 14 & FS & p.Thr2412fs & 3 & Morocco & $\mathrm{BC}$ & Familial & {$[9,12]$} \\
\hline c.7235_7236insG & 14 & FS & p.Lys2413fs & 1 & Morocco & OC & Familial & {$[15]$} \\
\hline c.7654dupA & 16 & FS & p.lle2552Asnfs2 & 2 & Algeria & $B C$ & Familial & {$[21,23]$} \\
\hline c.7654dupT & 16 & FS & p.lle2552fs & 2 & Tunisia & $B C$ & Familial & {$[27]$} \\
\hline$c .8485 C>T$ & 19 & NS & p.Gln2829 & 1 & Algeria & $B C$ & familial & [23] \\
\hline Del exons 19-20 & $19 / 20$ & LGR & - & 1 & Algeria & $\mathrm{BC}$ & familial & {$[21]$} \\
\hline c.8940delA & 22 & FS & p.Glu2981Lysfs7 & 1 & Algeria & $\mathrm{BOC}$ & Familial & [23] \\
\hline c.9097delA & 22 & FS & p.Thr3033Leufs & 1 & Tunisia & $B C$ & Familial & [32] \\
\hline$c .9364 G>A$ & 25 & MS & p.Ala3122Thr & 1 & Algeria & $B C$ & familial & {$[22]$} \\
\hline
\end{tabular}

FS: frameshift mutation, LGR: Large genomic rearrangement, MS: missense mutation, BC: breast cancer, OC: ovarian cancer, BOC: breast and ovarian cancer, NS: Nonsense mutation

families are consistent with this haplotype, supporting the founder effect of c.5309G $>\mathrm{T}$ in Morocco [13, 35, 36]. This mutation was first reported in Spain in two families of Moroccan origin and was classified as probably pathogenic on the basis of a combination of functional and structural analyses [17]. The c.5309G>T variant in $B R C A 1$ gene is located in the functionally important $B R C A 1$ carboxyl-terminal domain, a domain known to harbor missense substitutions associated with increased risk of $\mathrm{BC}$ and/or OC. The c.5309G $>\mathrm{T}$ variant should 
be treated as a disease-causing variant despite a lack of evolutionary conservation of the glycine at position 1770 [35].

The $B R C A 1 \mathrm{c} .3279 \mathrm{delC}$ variant mutation is a recurring $\mathrm{PV}$ in the Moroccan population. It accounts for $12.2 \%$ $(6 / 49)$ of the BRCA1 mutations [9, 11, 15], suggesting a possible founder effect. This mutation has been identified in one HBOC kindred of Dutch descent as well as in one HBOC kindred of Moroccan descent in which the proband and her mother were diagnosed with $\mathrm{BC}$ at younger ages $[9,37]$. The c.3279delC variant, located in coding exon 9 of the BRCA1 gene, is a frameshift variant of one base $(C)$ deletion that changes a tyrosine to isoleucine at codon 1094 and creates a premature stop codon at position 15 of the new reading frame.

The BRCA2 c.1310_1313delAAGA frameshift PV is considered as a North African recurrent mutation since it has been identified in Moroccan [12, 14], Algerian [20], and Tunisian [28] BC patients. Interestingly, geographical clustering in the North-Eastern area of Morocco is evident for the c.1310_1313delAAGA mutation, suggesting a founder effect [14]. c.1310_1313delAAGA incidence rate is high and accounts for $50 \%$ (17/34) of all BRCA2 PVs in North-East of Morocco [14]. This sequence change harbors the deletion of four nucleotides from exon 10 of the BRCA2 mRNA, causing a frameshift after codon 437 and the creation of a premature translational stop signal 22 amino acid residues.

\section{Discussion}

$B R C A$ genes remain the primary inherited causes of $\mathrm{BC}$ and $\mathrm{OC}$, accounting for $30-70 \%$ of hereditary BC families and approximately $90 \%$ of hereditary OC families. $B R C A$ PV carriers are linked with an increased lifetime risk of developing $\mathrm{BC}$ and/or OC. Current investigations have reported several differences and significant heterogeneity in the incidence and geographic distribution of PVs in BRCA genes [7,38]. In North Africa, BRCA PVs frequency varies widely from $\approx 1 \%$ (Morocco) in sporadic $\mathrm{BC}$ [10] to $37.5 \%$ (Tunisia) in HBOC [24]. The spectrum and prevalence of $B R C A$ PVs vary mainly due to population-specific recurrent/founder variants. Some of which have documented a founder effect of such recurrent or unique variants through haplotype analysis. Prevalence studies of $B R C A$ gene variants suggest that these genetic alterations can explain a high-frequency $\mathrm{BC}$ in some populations than others and may contribute to differences in cancer risk between populations and racial/ethnic minorities [5-7]. Accurate identification of the population-specific variant spectrum is therefore the first step towards incorporating appropriate $B R C A$ genetic testing into clinical practice in certain populations and racial/ethnic groups [39].
In North Africa, $B R C A 1$ founder variants explain around $36.4 \%(47 / 129)$ of $\mathrm{BC}$ and outnumber $B R C A 2$ founder variants by a ratio of $\approx 3: 1$. Clear founder effects have been reported in Morocco (BRCA1 c.5309G $>\mathrm{T}$ ) and Tunisia (BRCA1 c.211dupA). Furthermore, the BRCA1 c.798_799detTT was identified in $14 \%(18 / 129)$ of BRCA1 carriers in North African populations. It was initially thought to be specific to Algeria $(19.23 \%, 5 / 26)[19,20]$, but later found to be prevalent in Tunisia $(7.4 \%, 4 / 54)[24,29,30]$ and Morocco $(18.4 \%, 9 / 49) \quad[9,10,15-18]$. Haplotype analysis of some families carrying these PV revealed the presence of a common allele [19]. The BRCA1 c.798_799detTT frameshift variant is cited twice in the Breast Cancer Information Core (BIC) database, without any ethnic origin indicated. Interestingly, the c.798_799delTT and c. $5309 \mathrm{G}>\mathrm{T}$ variants in BRCA1 have been identified in sporadic BC patients in North Africa, and hence their presence in patients without a history of $\mathrm{BC}$ and/or OC cannot be attributed to the de novo mutational event. To our knowledge, the BRCA1 c.798_799delTT variant has been identified in Spain [40], in southern Italy [41, 42], and in France [43]. This restricted geographical distribution to close Mediterranean countries could be explained by geographical proximity and migration flow history. The c.1310_1313delAAGA variant in BRCA2 represents another common PV in North African populations whose founder effect through haplotype analysis is required for confirmation in this region. According to the BIC database, the BRCA2 c.1310_1313delAAGA PV was found in different European patients and was recorded several times in the French Universal Mutation database-BRCA2 (UMD-BRCA2) and classified as founder variant [44]. The c.1310_1313delAAGA PV, located in coding exon 9 of the BRCA2 gene, results from a deletion of four nucleotides at nucleotide positions 1310 to 1313 . The deletion causes a frameshift, which changes a Lysine to an Isoleucine at codon 437, and creates a premature stop codon at position 22 of the new reading frame. In addition, it is important to highlight that one of the three Ashkenazi Jewish founder variants (i.e. BRCA1 c.5266dup) is frequently observed in Tunisian BRCA1 carriers $(20.4 \%, 11 / 54)$. The BRCA1 c.5266dup has been mainly observed in Italy in some families from the North-eastern coast of Sicily [45]. BRCA1 c.5266dup was reported as a founder variant also in several European populations with a low proportion of individuals who self-identify as Jewish [46]. Previous studies indicate that the mutation was introduced into the Ashkenazi Jewish genetic pool approximately 400-500 years ago in Poland, but the mutation originated from a single common European ancestor long before it became an Ashkenazi 
Jewish founder mutation [47]. The BRCA1 c.5266dupC variant is the second most frequently reported PV in the BIC database.

Besides recurrent/founder variants, two BRCA1 PVs (c.211dupA and c.5309G $>$ T) identified in North Africa were not reported previously. The c.211dupA and c.5309G $>\mathrm{T}$ variants in the BRCA1 gene were found as unique to the Tunisian and Moroccan populations, respectively [24, 25, 27, 28, 31]. Several founder variants as they have common ancestral haplotypes have been identified in various areas and races. For example, the well-known founder variants are c.68_69delAG, c.5266dupC in BRCA1, and c.5946_5946delT in $B R C A 2$ in the Ashkenazi Jewish population [48, 49]. The c.824_825ins10, c.1713_1717delAGAAT, c.5177_5180del4, c.4357+1G>A variants in BRCA1 and c.4471_4474delCTGA variant in BRCA2 have been identified as a potential Afro-American founder variant [5052]. A high frequency of founder c.771_775del5 BRCA2 PV was identified in Iceland [53]. The founder BRCA2 c.771_775del5 variant was reported to cause the familial clustering of both female and male BC cases [53, 54]. The c.2685_2686del variant in BRCA1 and c.9672dup variant in $B R C A 2$ have been reported as founder mutations for the Dutch population [55]. A French-Canadian founder status is evident for c.4327 $\mathrm{C}>\mathrm{T}$ in $B R C A 1$ and c.8537_8538delAG in BRCA2 [56]. The founder effect of c.68_69delAG, c.181T>G, c.676delT, c.1687 C>T, c.3700_3704delGTAAA, c.3756_3759delGTCT, c.4035delA, c.5251 C>T, c.5266dupC in BRCA1 and c.658_659delGT, c.3847_3848delGT, c.5946delT, c.7913_7917delTTCCT in BRCA2 is characteristic of Central European population [46]. In BRCA1 gene, three large genomic deletions (deletion of exon 20, exon 24, and exons 23, and 24) and the c.5212G >A PV have been characterized as population-specific founder variants by haplotype analysis in the Greek population [57]. The c.1140dupG and c.4136_4137delCT variants in BRCA1 were identified as novel putative founder variants in Middle Eastern patients [58]. In Addition to c.2641G $>\mathrm{T}$, c.68_69delAG, c.5266dupC, and c.1374delC recurrent variants in BRCA1, haplotype analysis confirmed the founder status of c.5771_5774del and c.7934del variants in $B R C A 2$ and revealed an additional founder variant in $B R C A 2$, c.582G $>A$, in South African families [59]. In Latin America, clear founder effects have been reported in Mexico (BRCA1 del exons 9-12), Brazil (BRCA1 c.5266dupC and BRCA2 c.156_157insAlu), and Colombia (BRCA1 c.3331_3334delCAAG, BRCA1 c.5123 C >A, and BRCA2 c.2808_2811delACAA) [60]. In the Middle Eastern population, nine PVs were recurrent in epithelial OC and founder mutation analysis revealed only two mutations (BRCA1 c.4136_4137delCT and BRCA1
c.1140dupG) sharing the same haplotypes thus representing founder mutations [61]. Studying the founder effect of these variants can provide a comprehensive analysis of a population's evolution and its migration pathways.

The identification of recurrent/founder variants is an extremely important step towards the improvement of genetic counseling since molecular testing can be targeted to the recurrent/founder variant allowing for a more rapid and less expensive test [30]. The high frequency of recurrent/founder variants, allowing for analyzing a large number of cases, might provide accurate information regarding their penetrance and distinguish factors that affect them. Once a risk factor is identified in one subgroup of PV carriers it would need to be tested through other PV carriers. Subsequently, it would need to be tested in a large population-based case-control study of patients with $\mathrm{BC}$ and/or $\mathrm{OC}$, in order to determine how important the risk factor is in the general population [62]. Furthermore, the evidence of differences in susceptibility and in age onset of cancer and in the type of cancers that develop among carriers of a founder variant could make it possible to define the role and importance of risk-modifying factors with the resulting improved disease management [5].

Furthermore, a specific variant in $B R C A$ genes has been found with high prevalence in restricted populations as a consequence of a founder effect. The specific founder variant of c.303T $>\mathrm{G}$ and c.2641G $>\mathrm{T}$ in $B R C A 1$ gene were reported in the Yoruba population from Nigeria [63] and in the Afrikaner population from South Africa [59], respectively. Geographical clustering of c.3481_3491del11 and c.5128G $>\mathrm{T}$ variants in BRCA1 in the Alsace-Lorraine region at the North-East and in the north-east of France, respectively, suggests a founder effect $[43,64]$. In the southwest of the Netherland, the founder effect of c.4186-1643_4357+2020del3835 variant in BRCA1 gene and c.5351dupA variant in BRCA2 gene were prevalent in Catholic (West Brabant clustering) and Protestant (South Beveland clustering) families, respectively, reflecting religious endogamy [65]. The c.4964_4982del19 variant in BRCA1 gene has been identified as a founder variant in a geographically and historically homogeneous population from Calabria, a south Italian region [66]. Significant regional founder effect has been demonstrated for c.3228_3229delAG, c.3285delA, c.1380dupA, and c.5062_5064del3 variants in BRCA1 gene in Tuscany in central Italy [67]. The c.5062_5064delGTT variant in BRCA1 gene and c.8537_8538delAG variant in $B R C A 2$ gene have been described as founder variants in Middle Sardinia and in South and Middle Sardinia, respectively [68]. Figlioli et al. showed that the BRCA1 c.190T $>\mathrm{C}$ is a founder variant in $\mathrm{BC}$ families 
from Bergamo province in the Northern Italian region [6]. The c.3048_3052dupTGAGA variant is the western Swedish BRCA1 founder variant [69]. The BRCA1 c.131G PV was considered a specific founder variant in the Lebanese population [70]. In Saudi Arabia, six PVs were reported to be unique and founder PVs in Saudis with OC; four in BRCA1 gene (c.711_712insTGAA, c.1140dupG, c.5054 C>T, c.5530delC) and two in BRCA2 gene (c.2667delT and c.5760_5770del11) genes [71].

The identification of specific $B R C A$ variants could allow us to identify new founder effects for some of these and to quantify the degree of homogeneity within a population. Moreover, it was essential for promoting and potentially advancing rapid founder-based $B R C A$ point-of-care technology as a time- and cost-effective alternative. This discovery can surely help oncologists and cancer genetics professionals to simplify their choices in the genetic screening on high-risk families, on the basis of their ethnic origin, through more accurate estimation of carrier probabilities of $B R C A$ variants. Understanding the contribution of specific variants to $B C$ risk in such a population will help to examine the possibility of conducting population-wide genetic testing for candidate variants that are over-represented in this population [72]. The most well-known and significant examples of recurrent/founder mutations in BRCA genes found worldwide are presented in Table 3.

The high rates of specific and recurrent/founder PVs have led to a scientifically valid initiative to offer limited genotyping platforms. Establishing a founder effect lies mainly in the reduction of costs. Cost remains a frequently mentioned barrier to genetic testing in some populations such as North Africa. If we manage to decrease costs, screening could be offered more widely and cover a larger number of women, and could offer the benefits of early or pre-symptomatic diagnosis. To date, the eligibility criteria for $B R C A 1$ and $B R C A 2$ genetic testing have been expanded and updated. Currently, both the National Comprehensive Cancer Network (NCCN) guidelines and European Society for Medical Oncology (ESMO) guidelines recommend genetic testing for $B R C A 1$ and BRCA2 genes to women also with personal history of cancer (e.g. multiple primary BCs, if first diagnosis was $\leq 50$ years old, early age of $\mathrm{BC}$, co-occurrence of $\mathrm{BC}$ and $\mathrm{OC}$, etc. [167]. The three Ashkenazi-Jewish founder PVs (c.66_67del, c.5266dup in BRCA1, and c.5946del in BRCA2) are offered as a variant testing panel for self-reported Ashkenazim. This approach is much less expensive than comprehensive gene sequencing. With advances in sequencing technologies, testing women for the panel of population-specific recurrent/founder variants may be a valuable advance for therapy decisions in $\mathrm{BC}$ and $\mathrm{OC}$ patients.

A panel of $B R C A 1$ and $B R C A 2$ variants, including close to 100 recurrent variants (HISPANEL), has been constructed with diverse variants from Hispanic women with $\mathrm{BC}$ from the USA, based on the information in manuscripts describing variants in $B R C A$ genes from Latin American countries and data bases [168]. In Poland, Łukomska et $a l$., recommend that all women with OC and first-degree female relatives should be tested for the panel of 18 founder variants in BRCA1, BRCA2, PALB2, and $R A D 51 C$ [169]. In addition to the known founder deleterious variants in the Chinese population, Jiang et al., highlight that the recurrent PVs in BC patients could be taken as candidate genetic screening loci for a more efficient genetic screening of this population [170]. Studies from Egypt suggest wider screening of the founder PVs (c.68_69del and c.5266dupC in BRCA1) among highrisk families using the Pyrosequencing technique that could be an excellent platform for $B R C A$ founder PVs analysis [171].

Identification of specific and recurrent/founder variants that could be included in a low-cost PV panel, used as a first line screening approach, would be useful in the North African region. Advance of a screening panel for specific/recurrent and founder PVs offers a simple, rapid, and affordable routine molecular diagnostic method for the clinical management of $\mathrm{BC}$ and/or OC patients and their unaffected family members [172]. The PVs panel can also include other recurrent worldwide PVs such as BRCA1c.1016dupA which has also been reported in other countries (Italy, Germany, and French-Canada), however allelotyping results indicated an independent origin of this PV. That would justify the inclusion of the BRCA1c.1016dupA into targeted variant screening panels in any population, irrespective of ethnic origin [44].

In addition, offering a Next Generation Sequencing (NGS)-based Multigene Panel Testing (MGPT) to $\mathrm{BC}$ and/or $\mathrm{OC}$ patients may significantly increase the detection rates of specific/recurrent and founder $\mathrm{PVs}$ in $\mathrm{BC}$ and/or OC predisposition genes beyond BRCA. PALB2, CHEK2, ATM, MUTYH, MSH2, and $R A D 51 C$ have been shown to be the most frequently altered gene in $\mathrm{BC}$ and/or OC patients with negative test result for BRCA PVs [173-175]. Several recurrent or founder PVs have been described among some of these genes. For example, the c.444+1G>A PV was detected in $29 \%$ of Slovenian patients with CHEK2 variant [176]. Two splicing PVs in CHEK2 gene, an Eastern European founder variant c.444+1G $>\mathrm{A}$ and a novel c. $319+2 \mathrm{~T}>\mathrm{A}$, were recently discovered in Finnish BC patients [177]. The PALB2 c.3113G $>\mathrm{A}$ PV was the most recurrent familial variant in Australian $B C$ patients 
Table 3 Examples of recurrent and founder mutations in BRCA1 and BRCA2 genes described in European and non-European countries

\begin{tabular}{|c|c|c|c|c|}
\hline & \multicolumn{2}{|l|}{$B R C A 1$} & \multicolumn{2}{|l|}{$B R C A 2$} \\
\hline & HGVS nomenclature & Effect on amino-acid & HGVS nomenclature & Effect on amino-acid \\
\hline \multicolumn{5}{|c|}{ African Countries by Population } \\
\hline Algerian [19] & c.798_799delTT* & p.Ser267Lysfs* & & \\
\hline $\begin{array}{l}\text { Egyptian } \\
{[73]}\end{array}$ & $\begin{array}{l}\text { c.68_69delAG* } \\
\text { c. } 181 \mathrm{~T}>\mathrm{G} \\
\text { c.4327C>T } \\
\text { c.5266dupC } \\
\text { c.5335delC }{ }^{*}\end{array}$ & $\begin{array}{l}\text { p.Glu23fs* } \\
\text { p.Cys61Gly } \\
\text { p.Arg1443Ter } \\
\text { p.Gln1756Profs } \\
\text { p.GIn1779Asnfs* }\end{array}$ & $\begin{array}{l}\text { c. } 771 \_775 \text { del } 5^{*} \\
\text { c. } 5335 \text { del }\end{array}$ & $\begin{array}{l}\text { p.Asn257Lysfs* } \\
\text { p.GIn1779Asnfs }\end{array}$ \\
\hline $\begin{array}{l}\text { Moroccan } \\
{[9,11,13-15,19]}\end{array}$ & $\begin{array}{l}\text { c.798_799delTT* } \\
\text { c.3279delC } \\
\text { c.5309G }>T^{*}\end{array}$ & $\begin{array}{l}\text { p.Ser267Lysfs* } \\
\text { p.Tyr1094llefs } \\
\text { p.Gly1770Val* }\end{array}$ & c.1310_1313detAAGA & p.Lys437llefs \\
\hline $\begin{array}{l}\text { Nigerian } \\
{[74]}\end{array}$ & $\begin{array}{l}\text { c.191G }>A \\
\text { c.303T>G* } \\
\text { c.1504_1508delTTAAA } \\
\text { c.1623dupG*c.3268C }>T \\
\text { c.4122_4123delTG } G^{*} \text { c.4240dupCc.5 } \\
\text { 324T>G* }\end{array}$ & $\begin{array}{l}\text { p.Cys64Tyr } \\
\text { p.Tyr101Ter* } \\
\text { p.Leu502Alafs } \\
\text { p.Asn542fs* } \\
\text { p.Gln1090Ter } \\
\text { p.Ser1374Argfs* } \\
\text { p.Leu1414fs } \\
\text { p.Met1775Arg* }\end{array}$ & $\begin{array}{l}\text { c.1310_1313delAAGA c.2402_2412 } \\
\text { del11c.8817_8820delGAAA }\end{array}$ & $\begin{array}{l}\text { p.Lys437llefs } \\
\text { p.Asn801fs } \\
\text { p.Lys2939fs }\end{array}$ \\
\hline $\begin{array}{l}\text { Senegalese } \\
{[75]}\end{array}$ & c.815_824dup $10^{*}$ & p.Thr276Afs* & & \\
\hline $\begin{array}{l}\text { South African } \\
\text { [59] }\end{array}$ & $\begin{array}{l}\text { c.68_69delAG } \\
\text { c.1374delC } \\
\text { c. } 2641 \mathrm{G}>T^{*} \\
\text { c.5266dupC } \\
\text { c. } 7934 \text { delG }^{*}\end{array}$ & $\begin{array}{l}\text { p.Glu23fs } \\
\text { p.Asp458Glufs } \\
\text { p.Glu881Ter* } \\
\text { p.GIn1756Profs } \\
\text { p.Arg2645Asnfs* }\end{array}$ & & \\
\hline $\begin{array}{l}\text { Tunisian } \\
{[19,28,30,31]}\end{array}$ & $\begin{array}{l}\text { c. } 211 \text { dupA* } \\
\text { c.798_799delTT* } \\
\text { c.5266dupC }\end{array}$ & $\begin{array}{l}\text { p.Arg71Lysfs } \\
\text { p.Ser267Lysfs } \\
\text { p.Gln1756Profs }\end{array}$ & c.1310_1313detAAGA & p.Lys437llefs \\
\hline \multicolumn{5}{|c|}{ American countries by population } \\
\hline $\begin{array}{l}\text { African American } \\
\text { [50-52] }\end{array}$ & $\begin{array}{l}\text { c.824_825ins } 10^{*} c .1713 \text { 1717delAG } \\
\text { AAT*C.4357+1G>A } \\
\text { c.498616T>CC.5177_5180delGAAA* } \\
\text { c. } 5251 C>T \\
\text { c. } 5324 T>G c .5387 C>A \\
\text { c. } 4485-1 G>A^{*}\end{array}$ & $\begin{array}{l}- \\
\text { p.Glu572fs* } \\
- \\
- \\
\text { p.Arg1726Lysfs* } \\
\text { p.Arg1751Ter } \\
\text { p.Met1775Arg } \\
\text { p.Ser1796Ter } \\
-\end{array}$ & c.4471_4474delCTGA & p.Leu1491Lysfs \\
\hline $\begin{array}{l}\text { Argentinian } \\
{[76]}\end{array}$ & $\begin{array}{l}\text { c.68_69delAG* } \\
\text { c.211A>G* } \\
\text { c.5266dupC }{ }^{*}\end{array}$ & $\begin{array}{l}\text { p.Glu23fs* } \\
\text { p.Arg71Gly* } \\
\text { p.Gln1756Profs* }\end{array}$ & c.2808_2811del4c.5946_5946delT* & $\begin{array}{l}\text { p.Ala938Profs } \\
\text { p.Ser1982Argfs* }\end{array}$ \\
\hline $\begin{array}{l}\text { Bahamian } \\
\text { [77-80] }\end{array}$ & 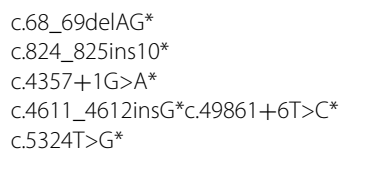 & $\begin{array}{l}\text { p.Glu23fs } \\
- \\
- \\
\text { p.GIn1538fs } \\
- \\
\text { p.Met1775Arg }\end{array}$ & c.7900delA* & p.Met2634fs X14 \\
\hline $\begin{array}{l}\text { Brazilian } \\
{[81-88]}\end{array}$ & $\begin{array}{l}\text { ins6Kb,c.68_69delAGc.211A>G* } \\
\text { c.1082C>G } \\
\text { c.2037delGinsCC } \\
\text { c.3331_3334delCAAG3261delGi } \\
\text { nsCC } \\
\text { c.3403C>T } \\
\text { c.5263dupC } \\
\text { c.5266dupC* }\end{array}$ & $\begin{array}{l}\text { p.Glu23fs } \\
\text { p.Arg71Gly* } \\
\text { p.Ser361Ter } \\
\text { p.Lys679fs } \\
\text { p.Gln1111fs* } \\
\text { - } \\
\text { p.Gln1135Ter } \\
\text { p.Glu1756Profs*4 } \\
\text { p.Gln1756Profs }\end{array}$ & $\begin{array}{l}\text { c.156_157insAlu* } \\
\text { c.3869G>A } \\
\text { c.4808delAc.5650_5659del } \\
\text { c.5946_5946delT } \\
\text { c.6405_6409delCTTAAc.6656C>G }\end{array}$ & $\begin{array}{l}\text { p.Lys53AlafsTerg* } \\
\text { p.Cys1290Tyr } \\
\text { p.Asn1603fs } \\
\text { p.lle1884fsp.Ser1982Argfs } \\
\text { p.Asn2135Lysfs } \\
\text { p.Ser2219Ter } \\
\text { p.Ser2219Ter }\end{array}$ \\
\hline $\begin{array}{l}\text { Chilean } \\
{[89,90]}\end{array}$ & $\begin{array}{l}\text { c.68_69delAG } \\
\text { c.211A>G } \\
\text { c.1504_1507delTTAA**2.2486_2487d } \\
\text { elTTc.3331_3334delCAAG* } \\
\text { 3759dupT* } \\
\text { c.3817C }>T^{*}\end{array}$ & $\begin{array}{l}\text { p.Glu23fs } \\
\text { p.Arg71Gly } \\
\text { p.Leu502Serfs* } \\
\text { p.Gly828_Phe829insTer } \\
\text { p.Gln1111fs* } \\
\text { p.Lys 1254Terfs* } \\
\text { p.Gln1273Ter* }\end{array}$ & $\begin{array}{l}\text { c. } 145 G>T^{*} \\
\text { c. } 4740 \_4741 \text { insTG**.5146_5149del4 } \\
{ }^{*} \text { C. } 6275 \_6276 \text { delT } \\
\text { c. } 8987 T>A^{*} \\
\text { c. } 9382 C<T^{*}\end{array}$ & $\begin{array}{l}\text { p.Glu49Ter* } \\
\text { p.Glu1581Trpfs* } \\
\text { p.Tyr1716LysfsTer8* } \\
\text { p.Leu2092Profs } \\
\text { p.Leu2996* } \\
\text { p.Arg3128Ter* }\end{array}$ \\
\hline
\end{tabular}


Table 3 (continued)

\begin{tabular}{|c|c|c|c|c|}
\hline & \multicolumn{2}{|l|}{ BRCA1 } & \multicolumn{2}{|l|}{$B R C A 2$} \\
\hline & HGVS nomenclature & Effect on amino-acid & HGVS nomenclature & Effect on amino-acid \\
\hline $\begin{array}{l}\text { Colombian } \\
{[91,92]}\end{array}$ & $\begin{array}{l}\text { c. } 114 G>A \\
\text { c. } 211 A>G^{*} \\
\text { c. } 2808 \_2811 \text { delACAA* } \\
\text { c. } 3331 \_3334 \text { delCAAG }{ }^{*} .4327 C>T^{*} \\
\text { c. } 5123 C>A^{*}\end{array}$ & $\begin{array}{l}\text { p.Lys38= } \\
\text { p.Gln1111fs } \\
\text { p.Ala1708Glu } \\
\text { p.Arg1443Ter } \\
\text { p.Ala1708Glu }\end{array}$ & $\begin{array}{l}\text { ex1-14del c.1763_1766delATAAc.28 } \\
\text { 08_2811del4* } \\
\text { c.6024dupG }\end{array}$ & $\begin{array}{l}\text { p.Asn588Serfs } \\
\text { p.Ala938Profs } \\
\text { p.GIn2009Alafs }\end{array}$ \\
\hline $\begin{array}{l}\text { Costa Rican } \\
{[93]}\end{array}$ & $\begin{array}{l}\text { c.68_69del } \\
\text { c.3403C>T } \\
\text { c.5266dupC* }\end{array}$ & $\begin{array}{l}\text { p.Glu23fs } \\
\text { p.Gln1135Ter } \\
\text { p.Gln1756Profs* }\end{array}$ & $\begin{array}{l}\text { c.5279C>G } \\
\text { c.5303_5304delTTC.5946_5946delT } \\
\text { c.6174delT }\end{array}$ & $\begin{array}{l}\text { p.Ser1760Ter } \\
\text { p.Leu1768fs } \\
\text { p.Ser1982Argfs } \\
\text { p.Phe2058fs }\end{array}$ \\
\hline $\begin{array}{l}\text { Cuban } \\
\text { [94] }\end{array}$ & & & $c .3166 C>T$ & p.GIn1056Ter \\
\hline $\begin{array}{l}\text { French Canadian } \\
{[56,95-98]}\end{array}$ & $\begin{array}{l}\text { c. } 962 \mathrm{G}>\mathrm{A} \\
\text { c.1016dupA } \\
\text { c.1961dupA } \\
\text { c. } 2125 \_2126 \text { insA } \\
\text { c. } 2834 \_2836 \text { delGTAinsC } \\
\text { c.3649_3650insA } \\
\text { c.3756_3759delGTCT } \\
\text { c.4327C>T* } \\
\text { c.3756_3759delGTCT } \\
\text { c.5102_5103delTG }\end{array}$ & $\begin{array}{l}\text { p.Trp321Ter } \\
\text { p.Val340GlyfsTer } \\
\text { p.Tyr655ValfsTer } \\
\text { p.Phe709TyrfsTer } \\
\text { p.Ser945ThrfsTer } \\
\text { p.Ser1217TyrfsTer } \\
\text { p.Ser1253ArgfsTer10 } \\
\text { p.Arg1443Ter* } \\
\text { p.Ser1253fs } \\
\text { p.Leu1701GInfsTer14 }\end{array}$ & $\begin{array}{l}\text { c. } 2588 \text { dupA } \\
\text { c. } 2806 \_2809 \text { delAAAC } \\
\text { c. } 3170 \_3174 \text { delAAAAG } \\
\text { c. } 3545 \_3546 \text { delTT } \\
\text { c. } 5857 G>T^{*} \\
\text { c. } 6275 \_6276 \text { delTT } \\
\text { c. } 8537 \_8538 d e l A G * \\
\text { c. } 9004 G>A\end{array}$ & $\begin{array}{l}\text { p.Asn863LysfsTer } \\
\text { p.Ala938ProfsTer21 } \\
\text { p.Lys1057fs } \\
\text { p.Phe1182Ter } \\
\text { p.Glu1953Ter* } \\
\text { p.Leu2092ProfsTer } \\
\text { p.Glu2846Glyfs* } \\
\text { p.Glu3002Lys }\end{array}$ \\
\hline $\begin{array}{l}\text { Fillipino } \\
\text { [99] }\end{array}$ & c.5335 delC* & p.Gln1779fs* & c.4631 delA* & p.Asn1544Thrfs* \\
\hline $\begin{array}{l}\text { Mexican } \\
{[100,101]}\end{array}$ & $\begin{array}{l}\text { c. } 211 \mathrm{~A}>\mathrm{G}^{*} \\
\text { c. } 212+1 \mathrm{G}>\mathrm{A} \\
\text { c.548-?_4185 ?del } \\
\text { exons } 9-12 \mathrm{del}^{*} \\
\text { ex8-9dup } \\
\text { ex18-19del } \\
\text { c.4327C }>T^{*}\end{array}$ & $\begin{array}{l}\text { p.Arg71Gly* } \\
- \\
- \\
- \\
- \\
- \\
\text { p.Arg1443Ter* }\end{array}$ & & \\
\hline $\begin{array}{l}\text { Peruvian } \\
\text { [102] }\end{array}$ & $\begin{array}{l}\text { c.68_69delAG } \\
\text { c. } 1961 \text { delA } \\
\text { c. } 4327 C>T^{*}\end{array}$ & $\begin{array}{l}\text { p.Glu23fs } \\
\text { p.Lys654fs } \\
\text { p.Arg1443Ter* }\end{array}$ & c.2808_2811del4 & p.Ala938Profs \\
\hline $\begin{array}{l}\text { Puerto Rican } \\
\text { [103] }\end{array}$ & & & c.3922G>T* & p.Glu1308Ter* \\
\hline \multicolumn{5}{|c|}{ Asian countries by population } \\
\hline $\begin{array}{l}\text { Ashkenazi Jewish } \\
{[49,104]}\end{array}$ & $\begin{array}{l}\text { c.68_69delAG* } \\
\text { c.5266dupC* }\end{array}$ & $\begin{array}{l}\text { p.Glu23fs* } \\
\text { p.Gln1756Profs* }\end{array}$ & c.5946_5946delT * & p.Ser1982Argfs* \\
\hline $\begin{array}{l}\text { Chinesse } \\
{[75,105-107]}\end{array}$ & $\begin{array}{l}\text { c.66dup } \\
\text { c. } 470 \_471 \text { delCT } \\
\text { c. } 981 \_982 \text { delAT* } \\
\text { c. } 1465 G>T \\
\text { c. } 3181 \text { del* } \\
\text { c. } 3257 \text { del c.3342_3345delAGAA } \\
\text { c.5406+1_5406+3delGTA } \\
\text { c.5470_5477delATTGGGCA* } \\
\text { c.981_982delAT* }\end{array}$ & $\begin{array}{l}\text { p.Glu23Argfs } \\
\text { p.Ser157Terfs } \\
\text { p.Cys328Terfs* } \\
\text { p.Glu489Ter } \\
\text { p.Glu1060_Ile1061insTer* } \\
\text { p.Arg1085_Leu1086insTer } \\
\text { p.Glu1115Terfs } \\
\text { - } \\
\text { p.lle1824Aspfs* } \\
\text { p.Cys328Terfs }\end{array}$ & $\begin{array}{l}\text { c. } 1832 \text { C>Ac.6591_6592delTG } \\
\text { c.1963delC c.2808_2811delACAA } \\
\text { c.3109C>T* } \\
\text { c.7436_7805del370* } \\
\text { c.9097_9098insA* }\end{array}$ & $\begin{array}{l}\text { p.Ser611Ter } \\
\text { p.Glu2198Asnfs } \\
\text { p.Arg655Glufs } \\
\text { p.Gln1037Ter* } \\
\text { p.Asp2479GlyfsX46* } \\
\text { p.T3033fs* }\end{array}$ \\
\hline $\begin{array}{l}\text { Indian } \\
{[108,109]}\end{array}$ & $\begin{array}{l}\text { c.68_69delAG c.178_179delCA } \\
\text { c.1016delA } \\
\text { c. } 2864 C>A \\
\text { c. } 3331 \_3334 \text { delCAAGc.4094delT } \\
\text { c. } 5074+1 G>A \\
\text { c. } 5137+1 G>A \\
\text { c. } 5098 d e l C \\
\text { c. } 5148 T>\text { G }\end{array}$ & $\begin{array}{l}\text { p.Glu23fs } \\
\text { p.Gln60Valfs } \\
\text { p.Lys339Argfs } \\
\text { p.Ser955Ter } \\
\text { p.Gln1111Asnfs } \\
\text { p.Leu1365Terfs } \\
- \\
\text { - } \\
\text { p.Thr1700fs } \\
\text { p.Tyr1716Ter }\end{array}$ & $\begin{array}{l}\text { c. } 682-2 A>G \\
\text { c. } 1907 C>G \\
\text { c. } 4638 d u p T \\
\text { c. } 4779 A>C c .5851 \_5854 \text { del4c.81 } \\
17 A>G \\
\text { c. } 5946 \text { delT* }\end{array}$ & $\begin{array}{l}\text { p.Ser636Ter } \\
\text { p.Asp1547Ter } \\
\text { p.Glu1593Asp } \\
\text { p.(Ser1951TrpfsTer11) } \\
\text { p.Asn2706Ser } \\
\text { p.Ser1982Argfs* }\end{array}$ \\
\hline $\begin{array}{l}\text { Iraqi } \\
\text { [110] }\end{array}$ & c.68_69delAG & p.Glu23fs & & \\
\hline
\end{tabular}


Table 3 (continued)

\begin{tabular}{|c|c|c|c|c|}
\hline & \multicolumn{2}{|l|}{ BRCA1 } & \multicolumn{2}{|l|}{$B R C A 2$} \\
\hline & HGVS nomenclature & Effect on amino-acid & HGVS nomenclature & Effect on amino-acid \\
\hline $\begin{array}{l}\text { Japanese } \\
{[111-113]}\end{array}$ & $\begin{array}{l}\text { c. } 307 \mathrm{~T}>\mathrm{A}^{*} \\
\text { c. } 188 \mathrm{~T}>\mathrm{A}^{*} \\
\text { c. } 2389 \mathrm{delGA} \\
\text { c. } 2800 \mathrm{C}>\mathrm{T}^{*} \\
\text { c. } 3442 \mathrm{delG}\end{array}$ & $\begin{array}{l}\text { p.Leu63Ter* } \\
\text { p.Glu797Thrfs } \\
\text { p.Gln934Ter* } \\
\text { p.Glu1148Argfs }\end{array}$ & $\begin{array}{l}\text { c. } 1278 \text { delA } \\
\text { c. } 2835 C>A^{*} \\
\text { c. } 5576 \_5579 \text { delTTAA* } \\
5802 \text { delAATT* } \\
\text { c. } 8504 C>A \\
\text { c. } 9117 \mathrm{G}>\mathrm{A} \\
\text { c. } 6952 \mathrm{C}>\mathrm{T} \\
\text { c. } 8589 \mathrm{dupA}\end{array}$ & $\begin{array}{l}\text { p.Asn433GInfs } \\
- \\
\text { p.lle1859Lysfs* } \\
- \\
\text { p.Ser2835Ter } \\
\text { p.Pro3039Pro } \\
\text { p.Arg2318Ter } \\
\text { p.Ala2864Serfs }\end{array}$ \\
\hline $\begin{array}{l}\text { Korean } \\
{[114]}\end{array}$ & & & $\begin{array}{l}\text { c. } 1399 A>T \\
\text { c. } 3744 \_3747 \text { delTGAG } \\
\text { c. } 7480 C>T^{*}\end{array}$ & $\begin{array}{l}\text { p.Lys467Ter } \\
\text { p.Ser1248Argfs } \\
\text { p.Arg2494Ter }\end{array}$ \\
\hline $\begin{array}{l}\text { Pakistani } \\
{[115-117]}\end{array}$ & $\begin{array}{l}\text { c. } 3770 \_3771 \text { del }^{*} \\
\text { c. } 4065 \_4068 \text { del }^{*} \text { C. } 4485-1 G>A^{*} \\
\text { c. } 4508 C>A^{*} \\
\text { c. } 5503 C>T^{*} \\
\text { exon } 1-2 \text { deletion* }\end{array}$ & $\begin{array}{l}\text { p.Glu1257Glyfs* } \\
\text { p.Asn1355Lysfs* } \\
\text { - } \\
\text { p.Ser1503* } \\
\text { p.Arg1835* } \\
\text { - }\end{array}$ & & \\
\hline $\begin{array}{l}\text { Vietnamese } \\
\text { [118] }\end{array}$ & $\begin{array}{l}\text { c.66dupA } \\
\text { c.5251C }>T\end{array}$ & $\begin{array}{l}\text { p.Glu23Argfs } \\
\text { p.Arg1751Ter }\end{array}$ & $\begin{array}{l}\text { c.1399A }>\text { T } \\
\text { c.3744_3747delTGAG } \\
\text { c. } 4478 \_4481 \text { delAAAG } \\
\text { c. } 7480 C>T\end{array}$ & $\begin{array}{l}\text { p.Lys467Ter } \\
\text { p.Ser1248Argfs } \\
\text { p.Glu1493Valfs } \\
\text { p.Arg2494Ter }\end{array}$ \\
\hline \multicolumn{5}{|c|}{ European countries by population } \\
\hline $\begin{array}{l}\text { Austrian } \\
{[119]}\end{array}$ & $\begin{array}{l}\text { c. } 181 T>G \\
\text { c. } 1687 C>T^{*} \\
\text { c. } 2676 \_2679 \text { delAAAG* } \\
\text { c. } 3016 \_3019 \text { del4 } \\
\text { c. } 5266 \text { dupC }\end{array}$ & $\begin{array}{l}\text { p.Cys61Gly } \\
\text { p.Gln563Ter* } \\
\text { p.Leu892_Lys893?fs* } \\
\text { p.His1006Glnfs } \\
\text { p.GIn1756Profs }\end{array}$ & $\begin{array}{l}\text { c.8363G }>\text { A } \\
\text { c. } 8754+1 G>\text { Ac. } 3860 \text { del }\end{array}$ & $\begin{array}{l}\text { p.Trp2788Ter } \\
\text { - } \\
\text { p.Asn1287fs }\end{array}$ \\
\hline $\begin{array}{l}\text { Belarusian } \\
\text { [120] }\end{array}$ & $\begin{array}{l}\text { c. } 181 \mathrm{~T}>\mathrm{G} \\
\text { c.5266dupC }\end{array}$ & $\begin{array}{l}\text { p.Cys61Gly } \\
\text { p.Gln1756Profs }\end{array}$ & & \\
\hline $\begin{array}{l}\text { Belgian } \\
{[121-123]}\end{array}$ & $\begin{array}{l}\text { c. } 212+3 A>G^{*} \\
\text { c.2359dupG* } \text { c.2685_2686delAA* } \\
\text { c.3661G }>T^{*}\end{array}$ & $\begin{array}{l}\text { p.Glu787Glyfs* } \\
\text { p.Pro897Lysfs* } \\
\text { p.Glu1221Ter* }\end{array}$ & $\begin{array}{l}\text { c.516+1G>A* } \\
\text { c. } 6275 \_6276 \text { delTT* } \\
\text { c.8904delC* }\end{array}$ & p.Leu2092ProfsTer7*p.Val2969fs ${ }^{*}$ \\
\hline $\begin{array}{l}\text { British } \\
{[124,125]}\end{array}$ & $\begin{array}{l}\text { c.2681_2682delAA*(Scotland) } \\
\text { c.4065_4068del4(NorthWest) } \\
\text { exon } 13 \text { duplication(ins6kbEx13) }\end{array}$ & $\begin{array}{l}\text { p.Lys894Thrfs* } \\
\text { p. Asn1355Lysfs10 } \\
\text { - }\end{array}$ & $\begin{array}{l}\text { c.6275_6276delTT* (Scotland) } \\
\text { c.1929delG (North-West) }\end{array}$ & p.Leu2092ProfsTer7* ${ }^{*}$ p.Arg645fs \\
\hline $\begin{array}{l}\text { Cypriot } \\
{[126,127]}\end{array}$ & & & c. 8755 delG* $^{*}$ & - \\
\hline $\begin{array}{l}\text { Czech } \\
{[128,129]}\end{array}$ & $\begin{array}{l}\text { c. } 181 \mathrm{~T}>\mathrm{G}^{*} \\
\text { c. } 5266 \mathrm{dupC} \mathrm{C}^{*} \\
\text { c. } 3700 \_3704 \text { del5* } \\
\text { exons } 1-17 \text { deletion* } \\
\text { exons 5-14 deletion* } \\
\text { c.7910_7914del5* }\end{array}$ & $\begin{array}{l}\text { p.Cys61Gly* } \\
\text { p.Gln1756Profs* } \\
\text { p.Cys61Gly } \\
\text { - } \\
\text { - } \\
\text { p.Phe2638Ter* }\end{array}$ & $\begin{array}{l}\text { c.7913_7917delTTCCT* } \\
\text { c.8537_8538del2* }\end{array}$ & $\begin{array}{l}\text { p.Phe2638Terfs* } \\
\text { p.Glu2846GlyfsTer22* }\end{array}$ \\
\hline $\begin{array}{l}\text { Danish } \\
\text { [130-132] }\end{array}$ & $\begin{array}{l}\text { c. } 2475 \text { delC } \\
\text { c.3319G }>\text { T } \\
\text { c.3710delT } \\
\text { exons 3-16 deletion* } \\
\text { c.5266dupC }\end{array}$ & $\begin{array}{l}\text { p.Asp825fs } \\
\text { p.Glu1107Ter } \\
\text { p.lle1237Asnfs } \\
\text { - } \\
\text { p.Gln1756Profs }\end{array}$ & $\begin{array}{l}\text { c.1310_1013del4 } \\
\text { c.3847_3848delGT } \\
\text { c.6373delA } \\
\text { c.6486_6489del4 }\end{array}$ & $\begin{array}{l}\text { p.Lys437llefsX22 } \\
\text { p.Val1283Lysfs } \\
\text { p.Thr2125Profs } \\
\text { p.Lys2162AsnfsTer5 }\end{array}$ \\
\hline $\begin{array}{l}\text { Finnish } \\
{[133-137]}\end{array}$ & $\begin{array}{l}\text { c. } 2684 \text { del2 } \\
\text { c.3485delA } \\
\text { c.3626delT } \\
\text { c. } 4096+3 A>G^{*} \\
\text { c. } 4097-2 A>G \\
\text { c. } 4327 C>T^{*} \\
\text { c. } 5251 C>T\end{array}$ & $\begin{array}{l}\text { p.Ala895fs } \\
\text { p.Asp1162Valfs } \\
\text { p.Lys1208_Leu1209insTer } \\
- \\
\text { - } \\
\text { p.Arg1443Ter* } \\
\text { p.Arg1751Ter }\end{array}$ & $\begin{array}{l}\text { c.8327T }>G^{*} C .771 \_775 \text { delTCAAA }{ }^{*} \mathrm{C} \\
.7480 C>T^{*} \\
\text { c. } 9117+1 G>A^{*} \\
\text { c. } 9118-2 A>G\end{array}$ & $\begin{array}{l}\text { p.Leu2776Ter* } \\
\text { p.Asn257Lysfs* } \\
\text { p.Arg2494Ter* } \\
\text { - } \\
\text { - }\end{array}$ \\
\hline $\begin{array}{l}\text { French } \\
{[43,64]}\end{array}$ & $\begin{array}{l}\text { c.3481_3491del11* }{ }^{*} \text { C.5030_5033del } \\
\text { CTAA c.5128G>T }\end{array}$ & $\begin{array}{l}\text { - } \\
\text { Thr1677llefs2 } \\
\text { p.Gly1710Ter }\end{array}$ & c.6644_6647delACTC & p.Tyr2215SerfsTer13 \\
\hline $\begin{array}{l}\text { German } \\
{[138-140]}\end{array}$ & $\begin{array}{l}\text { c. } 181 \mathrm{~T}>\mathrm{G} \\
\text { c. } 2338 \mathrm{C}>\mathrm{T} \\
\text { c. } 4065 \_4068 \text { del } 4 \\
\text { Exon } 17 \text { deletion* } \\
\text { c. } 5266 \text { dupC* }\end{array}$ & $\begin{array}{l}\text { p. Cys61Gly } \\
\text { p.GIn780Ter } \\
\text { p. Asn1355Lysfs10 } \\
\text { - } \\
\text { p.GIn1756Profs }\end{array}$ & $\begin{array}{l}\text { c. } 1813 \text { dupA } \\
\text { c. } 4478 \text { del4 } \\
\text { c. } 9098 \text { dupA }\end{array}$ & $\begin{array}{l}\text { p. Ile605Asnfs } 11 \\
\text { p.Glu1493Valfs } \\
\text { p.Gln3034fs }\end{array}$ \\
\hline
\end{tabular}


Table 3 (continued)

\begin{tabular}{|c|c|c|c|c|}
\hline & \multicolumn{2}{|l|}{$B R C A 1$} & \multicolumn{2}{|l|}{$B R C A 2$} \\
\hline & HGVS nomenclature & Effect on amino-acid & HGVS nomenclature & Effect on amino-acid \\
\hline $\begin{array}{l}\text { Greek } \\
{[141,142]}\end{array}$ & $\begin{array}{l}\text { c. } 5212 \mathrm{G}>\mathrm{A}^{*} \\
\text { c. } 5251 \mathrm{C}>\mathrm{T} \\
\text { c. } 5266 \mathrm{dupC} \mathrm{C}^{*} \\
\text { c. } 5467 \mathrm{G}>\mathrm{A} \\
3782 \mathrm{del} 10 \\
4512 \text { ins } \mathrm{T}\end{array}$ & $\begin{array}{l}\text { p.Gly1738Arg* } \\
\text { p.Arg1751Ter } \\
\text { p.Gln1756Profs* } \\
\text { p.Ala1823Thr } \\
\text { - } \\
-\end{array}$ & c.4284dup* & p.Gln1429fs* \\
\hline $\begin{array}{l}\text { Hungarians } \\
\text { [143] }\end{array}$ & $\begin{array}{l}\text { c.68_69delAG } \\
\text { c. } 181 \mathrm{~T}>\mathrm{G}^{*} \\
\text { c.5266dupC* }\end{array}$ & $\begin{array}{l}\text { p. Glu23fs } \\
\text { p. Cys61Gly* } \\
\text { p.Gln1756Profs* }\end{array}$ & $\begin{array}{l}\text { c.9097dupA } \\
\text { c.5946delT** }\end{array}$ & $\begin{array}{l}\text { p.Thr3033Asnfs } \\
\text { p.Ser1982Argfs* }\end{array}$ \\
\hline $\begin{array}{l}\text { Icelandic } \\
{[53,54]}\end{array}$ & & & c.771_775del5* & p.Asn257Lysfs* \\
\hline $\begin{array}{l}\text { Italian } \\
{[67,144,145]}\end{array}$ & $\begin{array}{l}\text { c. } 116 G>A^{*} \\
\text { c. } 3228 \_3229 \text { delAG*(Tuscany) } \\
\text { c. } 3285 \text { delA*(Tuscany) } \\
\text { c. } 1380 \text { dupA* (Tuscany) } \\
\text { c. } 5062 \_5064 \text { del3* (Tuscany) } \\
\text { c. } 4964 \_4982 \text { del19* (Calabria) } \\
\text { c.5062_5064delGTT*(Nordeast) }\end{array}$ & $\begin{array}{l}\text { p. Cys39Tyr* } \\
\text { p.Gly1077Alafs* } \\
\text { p.Lys1095Asnfs* } \\
\text { p.Phe461llefs* } \\
\text { p. Val1688del* } \\
\text { p.Ser1655Tyrfs* } \\
\text { p. Val1688del* }\end{array}$ & c.8537_8538delAG* (Sardinia) & p.Glu2846Glyfs* \\
\hline $\begin{array}{l}\text { Irish } \\
{[146]}\end{array}$ & $c .427 \mathrm{G}>T^{*}$ & p.Glu143Ter* & & \\
\hline $\begin{array}{l}\text { Lativian } \\
\text { [147] }\end{array}$ & $\begin{array}{l}\text { c. } 4035 \text { delA* } \\
\text { c.5266dupc }\end{array}$ & $\begin{array}{l}\text { p.Glu1346fs* } \\
\text { p.Gln1756Profs }\end{array}$ & & \\
\hline $\begin{array}{l}\text { Lithuanian } \\
{[148,149]}\end{array}$ & $\begin{array}{l}\text { c. } 4035 \text { delA* } \\
\text { c.5266dupC }\end{array}$ & $\begin{array}{l}\text { p.Glu1346fs* } \\
\text { p.Gln1756Profs }\end{array}$ & & \\
\hline $\begin{array}{l}\text { Norwegian } \\
{[150,151]}\end{array}$ & 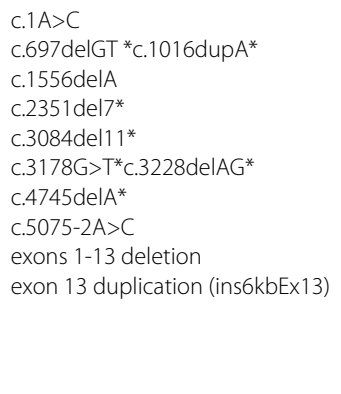 & $\begin{array}{l}\text { p.Met1Val } \\
\text { p.Val233Ter* } \\
\text { p.Val340Glyfs* } \\
\text { p.Lys519Argfs } \\
\text { p.Ser784Trpfs* } \\
\text { p.Asn1029Argfs* } \\
\text { p.Glu1060Ter* } \\
\text { p.Gly1077Alafs* } \\
\text { p.Asp1582fs* } \\
\text { - } \\
\text { - } \\
\text { - } \\
\text { - }\end{array}$ & $\begin{array}{l}\text { c. } 2808 \text { del }^{*} \\
\text { c.3847delGT* }\end{array}$ & $\begin{array}{l}\text { p.Ala938Profs* } \\
\text { p. Val1283fs* }\end{array}$ \\
\hline $\begin{array}{l}\text { Polish } \\
\text { [152] }\end{array}$ & $\begin{array}{l}\text { c. } 181 T>G^{*} \\
\text { c.3700_3704del5 } \\
\text { c. } 4035 \text { delA } \\
\text { c.5266dupC* }\end{array}$ & $\begin{array}{l}\text { p.Cys61Gly* } \\
\text { p.Val1234fs } \\
\text { p.Glu1346fs } \\
\text { p.Gln1756Profs* }\end{array}$ & & \\
\hline $\begin{array}{l}\text { Portuguese } \\
\text { [87] }\end{array}$ & & & c.156_157insAlu* & p.Lys53AlafsTer9* \\
\hline $\begin{array}{l}\text { Russian } \\
\text { [153] }\end{array}$ & $\begin{array}{l}\text { c.68_69delAG } \\
\text { c. } 181 \mathrm{~T}>\mathrm{G}^{*} \\
\text { c.4034delA } \\
\text { c.5266dupC* }\end{array}$ & $\begin{array}{l}\text { p. Glu23fs } \\
\text { p.Cys61Gly* } \\
\text { p.Glu1346fs } \\
\text { p.Gln1756Profs* }\end{array}$ & & \\
\hline $\begin{array}{l}\text { Scandinavian } \\
{[154]}\end{array}$ & $\begin{array}{l}\text { c.2475delC } \\
\text { c.5266dupC }\end{array}$ & $\begin{array}{l}\text { p.Asp825fs } \\
\text { p.Gln1756Profs }\end{array}$ & & \\
\hline $\begin{array}{l}\text { Scottish/ Northern Irish } \\
\text { [155] }\end{array}$ & c.2681_2682delAA & p.Lys894fs & c.6275_6276delTT & p.Leu2092Profs \\
\hline $\begin{array}{l}\text { Slovenian } \\
\text { [156-158] }\end{array}$ & $\begin{array}{l}\text { c. } 181 \mathrm{~T}>\mathrm{G}^{*} \\
\text { c. } 181 \mathrm{~T}>\mathrm{A} \\
\text { c. } 1687 \mathrm{C}>\mathrm{T} \\
\text { c. } 5266 \mathrm{dupC}\end{array}$ & $\begin{array}{l}\text { p.Cys61Gly* } \\
\text { p.Cys61Ser } \\
\text { p.GIn563Ter } \\
\text { p.GIn1756Profs }\end{array}$ & $\begin{array}{l}\text { c. } 6589 \mathrm{del} A^{*} \\
\text { c. } 7806-2 \mathrm{~A}>\mathrm{G}^{*}\end{array}$ & p.Thr2197fs \\
\hline $\begin{array}{l}\text { Spanish } \\
{[159-161]}\end{array}$ & $\begin{array}{l}\text { c. } 68 \_69 \text { delAG* } \\
\text { c. } 211 \mathrm{~A}>\mathrm{G}^{*} \text { (Galicia) } \\
\text { c. } 2900 \_2901 \text { dupCT } \\
\text { c. } 3331 \_3334 \text { delCAAG } \\
\text { c. } 5117 \mathrm{G}>\mathrm{A} \\
\text { c. } 5123 \mathrm{C}>\mathrm{A} \\
\text { c. } 470 \_471 \text { delCT } \\
\text { c. } 5153-1 \mathrm{G}>\mathrm{A}\end{array}$ & $\begin{array}{l}\text { p.Glu23Valfs* } \\
\text { p.Arg71Gly* } \\
\text { p.Pro968Leufs } \\
\text { p.GIn1111Asnfs } \\
\text { p.Gly1706Glu } \\
\text { (p.Ala1708Glu) } \\
\text { p.Leu156_Ser157insTer } \\
\text { - }\end{array}$ & $\begin{array}{l}\text { c.1813dupA } \\
\text { c.2095C>T } \\
\text { c.2808_2811del4 } \\
\text { c.4030_4035delinsC } \\
\text { c.5146_5149del4 } \\
\text { c.6629_6630delAA } \\
\text { c.9026_9030del5 } \\
\text { c.9310_9311delAA }\end{array}$ & $\begin{array}{l}\text { p.lle605Asnfs } \\
\text { p.Gln699 } \\
\text { p.Ala938Profs } \\
\text { p.Asn1344fs } \\
\text { p.Tyr1716Lysfs } \\
\text { p.Glu2210fs } \\
\text { p.Tyr3009Serfs } \\
\text { p.Lys3104ValfsTer }\end{array}$ \\
\hline
\end{tabular}


Table 3 (continued)

\begin{tabular}{|c|c|c|c|c|}
\hline & \multicolumn{2}{|l|}{$B R C A 1$} & \multicolumn{2}{|l|}{$B R C A 2$} \\
\hline & HGVS nomenclature & Effect on amino-acid & HGVS nomenclature & Effect on amino-acid \\
\hline $\begin{array}{l}\text { Swedish } \\
{[69,162-166]}\end{array}$ & $\begin{array}{l}\text { c.1082_1092del11* } \\
\text { c.1016dupA } \\
\text { c. } 1687 \text { C >T* } \\
\text { c. } 2475 \text { delC* } \\
\text { c.3048_3052dupTGAGA* } \\
\text { c.3171_3175dup* } \\
\text { c.3626delT* (Northern) } \\
\text { exon } 13 \text { duplication (ins6kbEx13) }\end{array}$ & $\begin{array}{l}\text { p.Cys360_Ser361insTer* } \\
\text { p.Val340LysfsX6 } \\
\text { p.GIn563Ter* } \\
\text { p.Asp825fs* } \\
\text { p.Asn1018Metfs* } \\
\text { p.Thr1189fs* } \\
\text { p.Lys1208_Leu1209insTer } \\
\text { - }\end{array}$ & c.4258delG & p.Asp1420fs \\
\hline
\end{tabular}

*Variant described in literature as a founder variant

[178]. Two recurrent PALB2 PVs (c.172_175delGA and c.509_510delGA) were observed in Polish BC and/or OC [179]. The c.159delT variant in PALB2 gene was identified as a founder PV in the Finnish population [180]. These genetic alterations can be identified in the European.

and non-European population and could be tested with the specific/recurrent and founder variants which occur in the BRCA genes for a targeted genetic screening of the first level using NGS-based MGPT. The identification of additional specific/recurrent and founder variants will be important for promoting and potentially advancing to rapid founder-based $B R C A$ and beyond $B R C A$ point-of-care technology as a time- and cost-effective alternative [181].

\section{Abbreviations}

ACMG-AMP: American College of Medical Genetics and Genomics-Association for Molecular Pathology; ASCO: American Society of Clinical Oncology; BC: Breast Cancer; BIC database: Breast Cancer Information Coredatabase; BRCA : BReastCAncer; HBOC: Hereditary breast and ovarian cancer; OC: Ovarian Cancer; PVs: Pathogenic Variants; UMD: Universal Mutation Database; VUS: Variant(s) of Unknown/uncertain Significance.

\section{Acknowledgements}

All authors thank Said HAMZAOUI for the English revision.

\section{Authors' contributions}

$\mathrm{OE}, \mathrm{AL}, \mathrm{FB}$ and have conceived the study, exploited data, coordinated and wrote the main manuscript. TB, CM, ML, HC, YS, and RT participated in the design. JK, MO, and MME generated data and were involved in data analyses. $\mathrm{HE}, \mathrm{AlL}, \mathrm{KB}, \mathrm{MI}, \mathrm{KE}, \mathrm{BB}$, and $\mathrm{YS}$ revised the manuscript. All authors read and approved the final manuscript.

\section{Funding}

Not applicable

\section{Availability of data and materials}

The datasets generated and analysed during the current study are available in the [Breast and ovarian cancer in North Africa (tables)] repository.

Pub med (Open access): https://pubmed.ncbi.nlm.nih.gov/

Science Direct (Open access): https://www.sciencedirect.com/

Google Scholar (Open access): https://scholar.google.com/

\section{Declarations}

Ethics approval and consent to participate

Not applicable

\section{Consent for publication}

Not applicable

\section{Competing interests}

The authors declare that they have no competing interests

\section{Author details}

${ }^{1}$ Laboratoire de Recherche et de Biosécurité P3, Hôpital Militaire d'Instruction Mohammed V, Rabat, Maroc. ${ }^{2}$ Unité de séquençage, Laboratoire de Virologie, Centre de Virologie, des Maladies Infectieuses et Tropicales, Hôpital Militaire d'Instruction Mohammed V, Faculté de Médecine et de Pharmacie, Université Mohammed V, Rabat, Maroc. ${ }^{3}$ Laboratoire de Biodiversité, Ecologie et Génome, Faculté des Sciences, Université Mohammed V, Rabat, Maroc. ${ }^{4}$ Centre de virologie, des maladies infectieuses et tropicales, Hôpital militaire d'Instruction Mohammed V, Faculté de Médecine et de Pharmacie, Université Mohammed V, Rabat, Maroc. ${ }^{5}$ Laboratoire de Biochimie-Toxicologie, Hôpital Militaire Moulay Ismail Meknès, Faculté de Médecine et de Pharmacie, Université Sidi Mohamed Ben Abdellah, Fès, Maroc. ${ }^{6}$ Laboratoire de Virologie, Microbiologie, Qualité, Biotechnologies/Ecotoxicologie et Biodiversité, Faculté des sciences et techniques, Mohammadia, Université Hassan II, Casa, Maroc. ${ }^{7}$ Service de Gynécologie Obstétrique, Hôpital militaire d'Instruction Mohammed V, Faculté de Médecine et de Pharmacie, Université Mohammed V, Rabat, Maroc. ${ }^{8}$ Laboratoire d'Anatomopathologie, Hôpital militaire d'Instruction Mohammed V, Faculté de Médecine et de Pharmacie, Université Mohammed V, Rabat, Maroc. ${ }^{9}$ Service d'Oncologie Médicale, Hôpital militaire d'Instruction Mohammed V, Faculté de Médecine et de Pharmacie, Université Mohammed V, Rabat, Maroc.

Received: 22 July 2021 Accepted: 24 November 2021

Published online: 25 February 2022

\section{References}

1. Sung H, Ferlay J, Siegel RL, Laversanne M, Soerjomataram I, Jemal A,et al. Global Cancer Statistics 2020: GLOBOCAN Estimates of Incidence and Mortality Worldwide for 36 Cancers in 185 Countries. CA Cancer J Clin. 2021,71:209-249.

2. World Health Organisation, "Latest global cancer data: Cancer burden rises to 18. 1 million new cases and 9.6 million cancer deaths in 2018 Latest global cancer data : Cancer burden rises to 18.1 million new cases and 9.6 million cancer deaths in 2018," Int. Agency Res. Cancer, no. September, pp.13-15, 2018.

3. Corbex M, Bouzbid S, Boffetta P. Features of breast cancer in developing countries, examples from North-Africa. Eur J Cancer. 2014,50:1808-8.

4. Caducee. http://www.caducee.net/ 
5. Ferla R, Calò V, Cascio S, Rinaldi G, Badalamenti G, Carreca I, Surmacz E, Colucci G, Bazan V, Russo A. Founder mutations in BRCA1 and BRCA2 genes. Ann Oncol. 2007,18:vi93-8.

6. Figlioli G, De Nicolo A, Catucci I, Manoukian S, Peissel B, Azzollini J, et al. Analysis of Italian BRCA1/2 pathogenic variants identifies a private spectrum in the population from the Bergamo province in Northern Italy. Cancers (Basel). 2021,13:532.

7. RebbeckTR, Friebel TM, Friedman E, Hamann U, Huo D, Kwong A, et al. Mutational spectrum in a worldwide study of 29,700 families with BRCA1 or BRCA2 mutations. Hum Mutat. 2018,39:593-620.

8. Laarabi FZ, Jaouad IC, Ouldim K, Aboussair N, Jalil A, Gueddari BE, et al. Genetic testing and first presymptomatic diagnosis in Moroccan families at high risk for breast/ovarian cancer. Oncol Lett. 2011,2:389-93.

9. Tazzite A, Jouhadi H, Nadifi S, Aretini P, Falaschi E, Collavoli A, et al. BRCA1 and BRCA2 germline mutations in Moroccan breast/ovarian cancer families: novel mutations and unclassified variants. Gynecol Oncol. 2012,125:687-92.

10. Laraqui A, Uhrhammer N, Lahlou-Amine I, El Rhaffouli $\mathrm{H}$, El Baghdadi J, Dehayni $\mathrm{M}$, et al. Mutation screening of the BRCA1 gene in early onset and familial breast/ovarian cancer in Moroccan population. Int J Med Sci. 2013,10:60-7

11. El Khachibi M, Diakite B, Hamzi K, Badou A, Senhaji MA, Bakhchane A, et al. Screening of exon 11 of BRCA1 gene using the high resolution melting approach for diagnosis in Moroccan breast cancer patients. BMC Cancer. 2015,15:81

12. Jouali F, Laarabi FZ, Marchoudi N, Ratbi I, Elalaoui SC, Rhaissi H, et al. First application of next-generation sequencing in Moroccan breast/ ovarian cancer families and report of a novel frameshift mutation of the BRCA1 gene. Oncol Lett. 2016,12:1192-96.

13. Quiles F, Teulé À, MartinussenTandstad N, Feliubadaló L, Tornero E, Del Valle J, et al. Identification of a founder BRCA1 mutation in the Moroccan population. Clin Genet. 2016, 90:361-5.

14. Laarabi FZ, Ratbi I, Elalaoui SC, Mezzouar L, Doubaj Y, Bouguenouch L, et al. High frequency of the recurrent c.1310_1313delAAGA BRCA2 mutation in the North-East of Morocco and implication for hereditary breast-ovarian cancer prevention and control. BMC Res Notes. 2017,10:188.

15. El Ansari FZ, Jouali F, Marchoudi N, Bennani MM, Ghailani NN, Barakat A, et al. Screening of $B R C A 1 / 2$ genes mutations and copy number variations in patients with high risk for hereditary breast and ovarian cancer syndrome (HBOC). BMC Cancer. 2020,20:747.

16. Bakkach J, Mansouri M, Derkaoui T, Loudiyi A, El Fahime E, Barakat A, et al. Contribution of BRCA1 and BRCA2 germline mutations to early onset breast cancer: a series from north of Morocco. BMC Cancer. 2020,20:859.

17. Mansouri M, Derkaoui T, Bakkach J, Loudiyi A, Nourouti NG, Barakat A, et al. Screening of BRCA1 and BRCA2 germline mutations in unselected triple-negative breast cancer patients: A series from north of Morocco. Precis Med Sci. 2020,9:43-48.

18. Jouali F, El Ansari FZ, Marchoudi N, Barakat A, Zmaimita H, Samlali H, et al. EGFR, BRCA1, BRCA2 and TP53 genetic profile in Moroccan triple negative breast cancer cases. Int J Mol Epidemiol Genet. 2020,11:16-25.

19. Uhrhammer N, Abdelouahab A, Lafarge L, Feillel V, Ben Dib A, Bignon YJ. BRCA1 mutations in Algerian breast cancer patients: high frequency in young, sporadic cases. Int J Med Sci. 2008,8:197-202.

20. Cherbal F, Bakour R, Adane S, Boualga K, Benais-Pont G, Maillet P. BRCA1 and BRCA2 germline mutations screening in Algerian breast/ovarian cancer families. Dis Markers. 2010,28:377-84.

21. Henouda S, Bensalem A, Reggad R, Serrar N, Rouabah L, Pujol P. Contribution of $B R C A 1$ and $B R C A 2$ germline mutations to early Algerian breast cancer. Dis Markers. 2016,2016:7869095.

22. Boulenouar ACS, Coulet F, Bendiab FMT, Boudinar FZ, Senhadji R. BRCA1 and BRCA2 germline mutation screening in Western Algeria using high resolution melting analysis (HRM). Gulf J Oncolog. 2018,1:31-37.

23. Mehemmai C, Cherbal F, Hamdi Y, Guedioura A, Benbrahim W, Bakour R et al. BRCA1 and BRCA2 germline mutation analysis in hereditary breast/ ovarian cancer families from the Aures Region (Eastern Algeria): First Report. Pathol Oncol Res. 2020,26:715-726.

24. Troudi W, Uhrhammer N, Sibille C, Dahan C, Mahfoudh W, BouchlakaSouissi $C$, et al. Contribution of the BRCA1 and BRCA2 mutations to breast cancer in Tunisia. J Hum Genet. 2007,52:915-20.
25. Troudi W, Uhrhammer N, Romdhane KB, Sibille C, Amor MB, Khodjet El $\mathrm{KhilH}$, et al. Complete mutation screening and haplotype characterization of BRCA1 gene in Tunisian patients with familial breast cancer. Cancer Biomark. 2008,4:11-8.

26. Mahfoudh W, Bouaouina N, Ahmed SB, Gabbouj S, Shan J, Mathew $\mathrm{R}$, et al. Hereditary breast cancer in Middle Eastern and North African (MENA) populations: identification of novel, recurrent and founder BRCA1 mutations in the Tunisian population. Mol Biol Rep. 2012,39:1037-46.

27. Riahi A, Kharrat M, Ghourabi ME, Khomsi F, Gamoudi A, Lariani I, et al. Mutation spectrum and prevalence of BRCA1 and BRCA2 genes in patients with familial and early-onset breast/ovarian cancer from Tunisia. Clin Genet. 2015,87:155-60

28. Fourati A, Louchez MM, Fournier J, Gamoudi A, Rahal K, El May MV, et al. screening for common mutations in BRCA1 and BRCA2 genes: interest in genetic testing of Tunisian families with breast and/or ovarian cancer Bull Cancer. 2014,101:E36-40.

29. Msolly A, Asma Kassab. BRCA1 and BRCA2 mutations are they related to breast cancer in a sample of Tunisian population? Cancer Therapy and Oncology International Journal, 2015,1:1-5.

30. Mahfoudh W, Bettaieb I, Ghedira R, Snoussi K, Bouzid N, Klayech Z, et al. Contribution of BRCA1 5382insC mutation in triple negative breast cancer in Tunisia. J Transl Med. 2019,17:123.

31. Mighri N, Hamdi Y, Boujemaa M, Othman H, Ben Nasr S, El Benna H, et al. Identification of novel BRCA1 and RAD50 mutations associated with breast cancer predisposition in Tunisian patients. Front Genet. 2020,11:552971.

32. Ben Ayed-Guerfali D, Ben Kridis-Rejab W, Ammous-Boukhris N, Ayadi W, Charfi S, Khanfir A, et al. Novel and recurrent BRCA1/BRCA2 germline mutations in patients with breast/ovarian cancer: a series from the south of Tunisia. J Transl Med. 2021,19:108.

33. Richards S, Aziz N, Bale S, Bick D, Das S, Gastier-Foster J, et al. ACMG Laboratory Quality Assurance Committee. Standards and guidelines for the interpretation of sequence variants: a joint consensus recommendation of the American College of Medical Genetics and Genomics and the Association for Molecular Pathology. Genet Med. 2015,17:405-24.

34. Backe J, Hofferbert S, Skawran B, Dörk T, Stuhrmann M, Karstens JH et al. Fequency of BRCA1 mutation 5382insC in German breast cancer patients. Gynecol Oncol. 1999,3:402-406.

35. Tudini $E$, Moghadasi S, Parsons MT, van der Kolk L, van den Ouweland AMW, Niederacher D, et al. Substantial evidence for the clinical significance of missense variant BRCA1 c.5309G $>$ T p.(Gly1770Val). Breast Cancer Res Treat. 2018,172:497-503

36. Quiles F, Fernández-Rodríguez J, Mosca R, Feliubadaló L, Tornero E, Brunet J, et al. Functional and structural analysis of C-terminal BRCA1 missense variants. PLoS One. 2013,8:e61302.

37. van der Hout $A H$, van den Ouweland $A M$, van der Luijt $R B$, Gille $H J$, Bodmer D, Brüggenwirth $\mathrm{H}$, et al. A DGGE system for comprehensive mutation screening of BRCA1 and BRCA2: application in a Dutch cancer clinic setting. Hum Mutat. 2006,27:654-66.

38. Manchanda R., Gaba F. Population based testing for primary prevention: A systematic review. Cancers. 2018,10:424.

39. Rashid MU, Muhammad N, Naeemi H, Khan FA, Hassan M, Faisal S, et al. Spectrum and prevalence of BRCA1/2 germline mutations in Pakistani breast cancer patients: results from a large comprehensive study. Hered Cancer Clin Pract. 2019,17:27.

40. John EM, Miron A, Gong G, Phipps Al, Felberg A, Li FP, et al. Prevalence of pathogenic BRCA1 mutation carriers in 5 US racial/ethnic groups. JAMA. 2007,298:2869-76.

41. Baudi F, Fabiani F, Leone E. Ten years of BRCA testing in calabrian population. Ann Oncol. 2009,20:89-106.

42. Russo A, Calò V, Agnese V, Bruno L, Corsale S, Augello C, et al. BRCA1 genetic testing in 106 breast and ovarian cancer families from Southern Italy (Sicily): a mutation analyses. Breast Cancer Res Treat. 2007,105:267-76.

43. Muller D, Bonaiti-Pellié C, Abecassis J, Stoppa-Lyonnet D, Fricker JP. BRCA1 testing in breast and/or ovarian cancer families from northeastern France identifies two common mutations with a founder effect. Fam Cancer. 2004,3:15-20.

44. Caputo S, Benboudjema L, Sinilnikova O, Rouleau E, Béroud C, Lidereau $\mathrm{R}$; French BRCA GGC Consortium. Description and analysis of genetic 
variants in French hereditary breast and ovarian cancer families recorded in the UMD-BRCA1/BRCA2 databases. Nucleic Acids Res. 2012,40:D992-1002.

45. Incorvaia L, Fanale D, Badalamenti G, Bono M, Calò V, Cancelliere D, et al. Hereditary Breast and Ovarian Cancer in Families from Southern Italy (Sicily)-Prevalence and Geographic Distribution of Pathogenic Variants in BRCA1/2 Genes. Cancers (Basel). 2020:12:1158.

46. Janavičius R. Founder BRCA1/2 mutations in the Europe: implications for hereditary breast-ovarian cancer prevention and control. EPMA J. 2010,1:397-12.

47. Hamel N, Feng BJ, Foretova L, Stoppa-Lyonnet D, Narod SA, Imyanitov $E$, et al. On the origin and diffusion of BRCA1 C.5266dupC (5382insC) in European populations. Eur J Hum Genet. 2011,19:300-6.

48. Struewing JP, Abeliovich D, Peretz T, Avishai N, Kaback MM, Collins FS, et al. The carrier frequency of the BRCA1 185delAG mutation is approximately 1\% in Ashkenazi Jewish individuals. Nat Genet. 1995,11:198-200.

49. Struewing JP, Hartge P, Wacholder S, Baker SM, Berlin M, McAdams M, et al. The risk of cancer associated with specific mutations of BRCA1 and BRCA2 among Ashkenazi Jews. N Engl J Med. 1997,336:1401-8.

50. Pal T, Bonner D, Cragun D, Monteiro AN, Phelan C, Servais L, Kim $J$, Narod SA, et al. A high frequency of BRCA mutations in young black women with breast cancer residing in Florida. Cancer. 2015,121:4173-80.

51. Olopade OI, Fackenthal JD, Dunston G, Tainsky MA, Collins F, WhitfieldBroome C. Breast cancer genetics in African Americans. Cancer. 2003,97:236-45

52. Pal T, Permuth-Wey J, Holtje T, Sutphen R. BRCA1 and BRCA2 mutations in a study of African American breast cancer patients. Cancer Epidemiol Biomarkers Prev. 2004,13:1794-9.

53. Thorlacius S, Sigurdsson S, Bjarnadottir H, Olafsdottir G, Jonasson JG, Tryggvadottir L. Study of a single BRCA2 mutation with high carrier frequency in a small population. Am J Hum Genet. 1997,60:1079-84.

54. Johannesdottir G, Gudmundsson J, Bergthorsson JT, Arason A, Agnarsson BA, Eiriksdottir G. High prevalence of the 999del5 mutation in Icelandic breast and ovarian cancer patients. Cancer Res. 1996,56:3663-5

55. Leegte $B$, van der Hout AH, Deffenbaugh AM, Bakker MK, Mulder IM, ten Berge A, et al. Phenotypic expression of double heterozygosity for BRCA1 and BRCA2 germline mutations. J Med Genet. 2005,42:e20.

56. Tonin PN, Mes-Masson AM, Futreal PA, Morgan K, Mahon M, Foulkes WD. Founder BRCA1 and BRCA2 mutations in French Canadian breast and ovarian cancer families. Am J Hum Genet. 1998,63:1341-51.

57. Fostira F, Kostantopoulou I, Apostolou P, Papamentzelopoulou MS, Papadimitriou C, Faliakou E. et al. One in three highly selected Greek patients with breast cancer carries a loss-of-function variant in a cancer susceptibility gene. J Med Genet. 2020,57:53-61.

58. Bu R, Siraj AK, Al-Obaisi KA, Beg S, Al Hazmi M, Ajarim D, et al. Identification of novel BRCA founder mutations in Middle Eastern breast cancer patients using capture and Sanger sequencing analysis. Int J Cancer. 2016,139:1091-7.

59. Reeves MD, Yawitch TM, van der Merwe NC, van den Berg HJ, Dreyer G, van Rensburg EJ. BRCA1 mutations in South African breast and/or ovarian cancer families: evidence of a novel founder mutation in Afrikaner families. Int J Cancer. 2004,110:677-82.

60. Ossa CA, Torres D. Founder and recurrent mutations in BRCA1 and $B R C A 2$ genes in Latin American countries: State of the art and literature review. Oncologist. 2016,21:832-9.

61. Siraj AK, Bu R, Iqbal K, Siraj N, Al-Haqawi W, Al-Badawi IA, et al. Prevalence, spectrum, and founder effect of BRCA1 and BRCA2 mutations in epithelial ovarian cancer from the Middle East. Hum Mutat. 2019,40:729-733.

62. Neuhausen SL. Founder populations and their uses for breast cancer genetics. Breast Cancer Res. 2000,2:77-81.

63. Zhang B, Fackenthal JD, Niu Q, Huo D, Sveen WE, DeMarco T, Adebamowo CA, Ogundiran T, Olopade Ol. Evidence for an ancient BRCA1 mutation in breast cancer patients of Yoruban ancestry. Fam Cancer. 2009,8:15-22

64. Ramus SJ, Gayther SA. The contribution of BRCA1 and BRCA2 to ovarian cancer. Mol Oncol. 2009,3:138-50.

65. Verhoog LC, van den Ouweland AM, Berns E, van Veghel-Plandsoen MM, van Staveren IL, Wagner A, et al. Large regional differences in the frequency of distinct BRCA1/BRCA2 mutations in 517 Dutch breast and/ or ovarian cancer families. Eur J Cancer. 2001,37:2082-90.

66. Baudi F, Quaresima B, Grandinetti C, Cuda G, Faniello C, Tassone P, et al. Evidence of a founder mutation of BRCA1 in a highly homogeneous population from southern Italy with breast/ovarian cancer. Hum Mutat. 2001,18:163-4.

67. Papi L, Putignano AL, Congregati C, Zanna I, Sera F, Morrone D, et al. Founder mutations account for the majority of BRCA1-attributable hereditary breast/ovarian cancer cases in a population from Tuscany, Central Italy. Breast Cancer Res Treat. 2009,117:497-504.

68. Malacrida S, Agata S, Callegaro M, Casella C, Barana D, Scaini MC, et al. BRCA1 p.Val1688del is a deleterious mutation that recurs in breast and ovarian cancer families from Northeast Italy. J Clin Oncol. 2008,26:26-31.

69. Einbeigi Z, Bergman A, Kindblom LG, Martinsson T, Meis-Kindblom JM, Nordling $\mathrm{M}$, et al. A founder mutation of the BRCA1 gene in Western Sweden associated with a high incidence of breast and ovarian cancer. Eur J Cancer. 2001,37:1904-9.

70. Geredeli C, Yasar N, Sakin A. Germline mutations in BRCA1 and BRCA2 in breast cancer patients with high genetic risk in Turkish population. Int J Breast Cancer. 2019:9645147

71. Alhuqail AJ, Alzahrani A, Almubarak H, Al-Qadheeb S, Alghofaili L, Almoghrabi N, ET al. High prevalence of deleterious BRCA1 and BRCA2 germline mutations in Arab breast and ovarian cancer patients. Breast Cancer Res Treat. 2018,168:695-702.

72. Behl S, Hamel N, de Ladurantaye M, Lepage S, Lapointe R, Mes-Masson AM, Foulkes WD. Founder BRCA1/BRCA2/PALB2 pathogenic variants in French-Canadian breast cancer cases and controls. Sci Rep. 2020,10:6491.

73. Ibrahim SS, Hafez EE, Hashishe MM. Presymptomatic breast cancer in Egypt: role of BRCA1 and BRCA2 tumor suppressor genes mutations detection. J Exp Clin Cancer Res. 2010,29:82.

74. Fackenthal JD, Zhang J, Zhang B, Zheng Y, Hagos F, Burrill DR, et al. High prevalence of $B R C A 1$ and $B R C A 2$ mutations in unselected Nigerian breast cancer patients. Int J Cancer. 2012,131:1114-23.

75. Zhang J, Fackenthal JD, Zheng Y, Huo D, Hou N, Niu Q, et al. Olopade Ol. Recurrent BRCA1 and BRCA2 mutations in breast cancer patients of African ancestry. Breast Cancer Res Treat. 2012,134:889-94.

76. Solano AR, Aceto GM, Delettieres D, Veschi S, Neuman MI, Alonso E, et al. BRCA1 and BRCA2 analysis of Argentinean breast/ovarian cancer patients selected for age and family history highlights a role for novel mutations of putative south-American origin. Springer plus. 2012,1:20.

77. Donenberg T, Lunn J, Turnquest T, Curling D, Krill-Jackson E, Royer R, et al. High frequency of BRCA1 founder mutations in the Bahamas. Cancer Res. 2009,69:4078-4078.

78. Donenberg T, Lunn J, Curling D, Turnquest T, Krill-Jackson E, Royer R, et al. A high prevalence of BRCA1 mutations among breast cancer patients from the Bahamas. Breast Cancer Res Treat. 2011,125:591-6.

79. Akbari MR, Donenberg T, Lunn J, Curling D, Turnquest T, Krill-Jackson $\mathrm{E}$, et al. The spectrum of BRCA1 and BRCA2 mutations in breast cancer patients in the Bahamas. Clin Genet. 2014,85:64-67.

80. Trottier M, Lunn J, Butler R, Curling D, Turnquest T, Francis W, et al. Prevalence of founder mutations in the BRCA1 and BRCA2 genes among unaffected women from the Bahamas. Clin Genet. 2016,89:328-331.

81. Ewald IP, Izetti P, Vargas FR, Moreira MA, Moreira AS, Moreira-Filho CA, et al. Prevalence of the BRCA1 founder mutation c.5266dupin Brazilian individuals at-risk for the hereditary breast and ovarian cancer syndrome. Hered Cancer Clin Pract. 2011,20;9:12.

82. Dillenburg CV, Bandeira IC, Tubino TV, Rossato LG, Dias ES, Bittelbrunn AC, Leistner-Segal S. Prevalence of 185delAG and 5382insC mutations in BRCA1, and 6174delT in BRCA2 in women of Ashkenazi Jewish origin in southern Brazil. Genet Mol Biol. 2012, 35:599-602.

83. Dufloth RM, Carvalho S, Heinrich JK, Shinzato JY, dos Santos CC, Zeferino LC, et al. Analysis of BRCA1 and BRCA2 mutations in Brazilian breast cancer patients with positive family history. Sao Paulo Med J. 2005,123:192-7.

84. Felix GE, Abe-Sandes C, Machado-Lopes TM, Bomfim TF, Guindalini RS, Santos VC, et al. Germline mutations in BRCA1, BRCA2, CHEK2 and TP53 in patients at high-risk for HBOC: characterizing a Northeast Brazilian Population. Hum Genome Var. 2014,1:14012. 
85. Esteves VF, Thuler LC, Amêndola LC, Koifman RJ, Koifman S, Frankel PP, Brazilian Network of Breast and Ovarian Familial Cancer Aggregation. Prevalence of $B R C A 1$ and $B R C A 2$ gene mutations in families with medium and high risk of breast and ovarian cancer in Brazil. Braz J Med Biol Res. 2009,42:453-7.

86. Silva FC, Lisboa BC, Figueiredo MC, Torrezan GT, Santos EM, Krepischi $A C$, e al. Hereditary breast and ovarian cancer: assessment of point mutations and copy number variations in Brazilian patients. BMC Med Genet. 2014,15:55.

87. Moreira MA, Bobrovnitchaia IG, Lima MA, Santos AC, Ramos JP, Souza KR, et al. Portuguese c.156_157insAlu BRCA2 founder mutation: gastrointestinal and tongue neoplasias may be part of the phenotype. Fam Cancer. 2012,11:657-60.

88. Gomes R, Soares BL, Felicio PS, Michelli R, Netto CBO, Alemar B, et al. Haplotypic characterization of BRCA1 c.5266dupC, the prevailing mutation in Brazilian hereditary breast/ovarian cancer. Genet Mol Biol. 2020,43:e20190072.

89. Jara L, Ampuero S, Santibáñez E, Seccia L, Rodríguez J, Bustamante M, et al. BRCA1 and BRCA2 mutations in a South American population. Cancer Genet Cytogenet. 2006, 1;166:36-45.

90. Jara L, Ampuero S, Seccia L, Bustamante M, Blanco R, Santibáñez E, et al. Frequency of the 185 delAG mutation in the BRCA1 gene in Chilean healthy women with family history of breast cancer. Rev médica Chile. 2002,130:1113-23.

91. Torres D, Rashid MU, Gil F, Umana A, Ramelli G, Robledo JF, et al. High proportion of BRCA1/2 founder mutations in Hispanic breast/ ovarian cancer families from Colombia. Breast Cancer Res Treat. 2007,103:225-32.

92. Torres D, Bermejo JL, Rashid MU, Briceño I, Gil F, Beltran A, et al. Prevalence and Penetrance of BRCA1 and BRCA2 Germline Mutations in Colombian Breast Cancer Patients. Sci Rep. 2017,7:4713.

93. Gutiérrez Espeleta GA, Llacuachaqui M, García-Jiménez L, Aguilar Herrera M, Loáiciga Vega $\mathrm{K}$, Ortiz $\mathrm{A}$, et al. BRCA1 and BRCA2 mutations among familial breast cancer patients from Costa Rica. Clin Genet. 2012,82:484-8.

94. Rodriguez RC, Esperon AA, Ropero R, Rubio MC, Rodriguez R, Ortiz $\mathrm{RM}$, et al. Prevalence of BRCA1 and BRCA2 mutations in breast cancer patients from Cuba. Fam Cancer. 2008,7:275-9.

95. Oros KK, Ghadirian P, Greenwood CM, Perret C, Shen Z, Paredes Y, et al. Significant proportion of breast and/or ovarian cancer families of French Canadian descent harbor 1 of $5 B R C A 1$ and BRCA2 mutations. Int J Cancer. 2004,112:411-9.

96. Oros KK, Leblanc G, Arcand SL, Shen Z, Perret C, Mes-Masson AM, et al. Haplotype analysis suggest common founders in carriers of the recurrent BRCA2 mutation, 3398delAAAAG, in French Canadian hereditary breast and/ovarian cancer families. BMC Med Genet. 2006,7:23.

97. Simard J, Dumont M, Moisan AM, Gaborieau V, Malouin H, Durocher F, et al. Evaluation of BRCA1 and BRCA2 mutation prevalence, risk prediction models and a multistep testing approach in French-Canadian families with high risk of breast and ovarian cancer [published correction appears in J Med Genet. 2007,44:471]. J Med Genet. 2007,44:107-121.

98. Cavallone L, Arcand SL, Maugard CM, Nolet S, Gaboury LA, Mes-Masson $A M$, et al. Comprehensive BRCA1 and BRCA2 mutation analyses and review of French Canadian families with at least three cases of breast cancer. Fam Cancer. 2010,9:507-17.

99. De Leon Matsuda ML, Liede A, Kwan E, Mapua CA, Cutiongco EM, Tan A, et al. BRCA1 and BRCA2 mutations among breast cancer patients from the Philippines. Int J Cancer. 2002,98:596-603.

100. Villarreal-Garza C, Alvarez-Gómez RM, Pérez-Plasencia C, Herrera LA, Herzog J, Castillo D, et al. Significant clinical impact of recurrent BRCAI and BRCA2 mutations in Mexico. Cancer. 2015,121:372-8.

101. Martínez-Treviño DA, León-Cachón RBR, Villarreal-Garza C, Aguilar Y Méndez D, Aguilar-Martínez E, Barrera-Saldaña HA. A novel method to detect the Mexican founder mutation BRCA1 ex912del associated with breast and ovarian cancer using quantitative polymerase chain reaction and TagMan ${ }^{\circledR}$ probes. Mol Med Rep. 2018,18:1531-37.

102. Abugattas J, Llacuachaqui M, Allende YS, Velásquez AA, Velarde R, Cotrina J, et al. Prevalence of BRCA1 and BRCA2 mutations in unselected breast cancer patients from Peru. Clin Genet. 2015 Oct;88(4):371-5.

103. Diaz-Zabala HJ, Ortiz AP, Garland L, Jones K, Perez CM, Mora E, et al. A Recurrent BRCA2 Mutation Explains the Majority of Hereditary Breast and Ovarian Cancer Syndrome Cases in Puerto Rico. Cancers (Basel). 2018,10:419.

104. Levy-Lahad E, Catane R, Eisenberg S, Kaufman B, Hornreich G, Lishinsky $E$, et al. Founder BRCA1 and BRCA2 mutations in Ashkenazi Jews in Israel: frequency and differential penetrance in ovarian cancer and in breast-ovarian cancer families. Am J Hum Genet. 1997,60:1059-67.

105. Zhi X, Szabo C, Chopin S, Suter N, Wang QS, Ostrander EA, et al. BRCA1 and BRCA2 sequence variants in Chinese breast cancer families. Hum Mutat. 2002,20:474.

106. Kwong A, Ng EK, Wong CL, Law FB, AuT, Wong HN,et al. Identification of BRCA1/2 founder mutations in Southern Chinese breast cancer patients using gene sequencing and high resolution DNA melting analysis. PLoS One. 2012,7:e43994.

107. Vaidyanathan K, Lakhotia S, Ravishankar HM, Tabassum U, Mukherjee G, Somasundaram K. BRCA1 and BRCA2 germline mutation analysis among Indian women from south India: identification of four novel mutations and high-frequency occurrence of 185delAG mutation. J Biosci. 2009,34:415-22.

108. Saxena S, Szabo Cl, Chopin S, Barjhoux L, Sinilnikova O, Lenoir G, et al. BRCA1 and BRCA2 in Indian breast cancer patients. Hum Mutat. 2002,20:473-4.

109. Chheda P, Pande S, Dama T, Vinarkar S, Chanekar M, Limaye S, et al. Spectrum of germline BRCA mutations in hereditary breast and ovarian cancer syndrome in Indian population: A central reference laboratory experience. Cancer Res Stat Treat 2020,3:32-41.

110. Bar-Sade RB, Kruglikova A, Modan B, Gak E, Hirsh-Yechezkel G, Theodor $\mathrm{L}$, et al. The 185delAG BRCA1 mutation originated before the dispersion of Jews in the diaspora and is not limited to Ashkenazim. Hum Mol Genet. 1998,7:801-5.

111. Sekine M, Nagata H, Tsuji S, Hirai Y, Fujimoto S, Hatae M, Japanese Familial Ovarian Cancer Study Group et al. Mutational analysis of BRCA1 and $B R C A 2$ and clinicopathologic analysis of ovarian cancer in 82 ovarian cancer families: two common founder mutations of BRCA1 in Japanese population. Clin Cancer Res. 2001,7:3144-50.

112. Ikeda N, Miyoshi Y, Yoneda K, Shiba E, Sekihara Y, Kinoshita M, et al. Frequency of $B R C A 1$ and $B R C A 2$ germline mutations in Japanese breast cancer families. Int J Cancer. 2001,91:83-8.

113. Matsushima M, Kobayashi K, Emi M, Saito H, Saito J, Suzumori K, et al. Mutation analysis of the BRCA1 gene in 76 Japanese ovarian cancer patients: four germline mutations, but no evidence of somatic mutation. Hum Mol Genet. 1995,4:1953-6.

114. Kang E, Kim SW. The Korean hereditary breast cancer study: review and future perspective. J Breast Cancer. 2013,16:245-253.

115. Liede A, Malik IA, Aziz Z, Rios Pd Pde L, Kwan E, Narod SA. Contribution of $B R C A 1$ and $B R C A 2$ mutations to breast and ovarian cancer in Pakistan. Am J Hum Genet. 2002,71:595-606.

116. Rashid MU, Zaidi A, Torres D, Sultan F, Benner A, Naqvi B, et al. Prevalence of BRCA1 and BRCA2 mutations in Pakistani breast and ovarian cancer patients. Int J Cancer. 2006,119:2832-9.

117. Rashid MU, Muhammad N, Amin A, Loya A, Hamann U. Contribution of $B R C A 1$ large genomic rearrangements to early-onset and familial breast/ ovarian cancer in Pakistan. Breast Cancer Res Treat. 2017,161:191-201.

118. Ginsburg OM, Dinh NV, To TV, Quang LH, Linh ND, Duong BT, et al. Family history, BRCA mutations and breast cancer in Vietnamese women. Clin Genet. 2011,80:89-92.

119. Wagner TM, Moslinger R, Zielinski C, Scheiner O, Breiteneder H. New Austrian mutation in BRCA1 gene detected in three unrelated $\mathrm{HBOC}$ families. Lancet. 1996,347:1263.

120. Oszurek O, Gorski B, Gronwald J, Prosolow Z, Uglanica K, Murinow A, et al. Founder mutations in the BRCA1 gene in west Belarusian breastovarian cancer families. Clin Genet. 200,60:470-1.

121. Claes K, Poppe B, Coene I, Paepe AD, Messiaen L. BRCA1 and BRCA2 germline mutation spectrum and frequencies in Belgian breast/ovarian cancer families. Br J Cancer. 2004,90:1244-51.

122. Peelen T, van Vliet M, Petrij-Bosch A, Mieremet R, Szabo C, van den Ouweland AM, et al. A high proportion of novel mutations in BRCA1 with strong founder effects among Dutch and Belgian hereditary breast and ovarian cancer families. Am J Hum Genet. 1997,60:1041-9.

123. Claes K, Machackova E, De Vos M, Poppe B, De Paepe A, Messiaen L. Mutation analysis of the BRCA1 and BRCA2 genes in the Belgian patient 
population and identification of a Belgian founder mutation BRCA1 IVS5 + 3A > G. Dis Markers. 1999,15:69-73.

124. Scottish/Northern Irish BRCA1/BRCA2 Consortium. BRCA1 and BRCA2 mutations in Scotland and Northern Ireland. Br J Cancer. 2003:88:1256-62.

125. Evans DG, Neuhausen SL, Bulman M, Young K, Gokhale D, Lalloo F. Haplotype and cancer risk analysis of two common mutations, BRCA1 4184del4 and BRCA2 2157delG, in high risk northwest England breast/ ovarian families. J Med Genet. 2004,41:e21.

126. Loizidou M, Marcou Y, Anastasiadou V, Newbold R, Hadjisavvas A, Kyriacou K. Contribution of BRCA1 and BRCA2 germline mutations to the incidence of early-onset breast cancer in Cyprus. Clin Genet. 2007,71:165-70

127. Hadjisavvas A, Charalambous E, Adamou A, Neuhausen SL, Christodoulou CG, Kyriacou K. Hereditary breast and ovarian cancer in Cyprus: identification of a founder BRCA2 mutation. Cancer Genet Cytogenet. 2004,151:152-6.

128. Machackova E, Foretova L, Lukesova M, Vasickova P, Navratilova M, Coene I, et al. Spectrum and characterisation of BRCA1 and BRCA2 deleterious mutations in high-risk Czech patients with breast and/or ovarian cancer. BMC Cancer. 2008,8:140.

129. Pohlreich P, Zikan M, Stribrna J, Kleibl Z, Janatova M, Kotlas J, et al. High proportion of recurrent germline mutations in the BRCA1 gene in breast and ovarian cancer patients from the Prague area. Breast Cancer Res. 2005,7:R728-36.

130. Bergthorsson JT, Ejlertsen B, Olsen JH, Borg A, Nielsen KV, Barkardottir $\mathrm{RB}$, et al. BRCA1 and BRCA2 mutation status and cancer family history of Danish women affected with multifocal or bilateral breast cancer at a young age. J Med Genet. 2001,38:361-8.

131. Soegaard M, Kjaer SK, Cox M, Wozniak E, Høgdall E, Høgdall C, et al. et al. $B R C A 1$ and BRCA2 mutation prevalence and clinical characteristics of a population-based series of ovarian cancer cases from Denmark. Clin Cancer Res. 2008,14:3761-7.

132. Thomassen M, Hansen TV, Borg A, Lianee HT, Wikman F, Pedersen IS, et al. BRCA1 and BRCA2 mutations in Danish families with hereditary breast and/or ovarian cancer. Acta Oncol. 2008,47:772-7.

133. Huusko P, Pääkkönen $K$, Launonen V, Pöyhönen M, Blanco G, Kauppila $A$, et al. Evidence of founder mutations in Finnish BRCA1 and BRCA2 families. Am J Hum Genet. 1998,62:1544-8.

134. Sarantaus $L$, Huusko $P$, Eerola $H$, Launonen V, Vehmanen $P$, Rapakko $K$, et al. Multiple founder effects and geographical clustering of $B R C A 1$ and BRCA2 families in Finland. Eur J Hum Genet. 2000,8:757-63.

135. Syrjäkoski K, Vahteristo P, Eerola H, Tamminen A, Kivinummi K, Sarantaus $\mathrm{L}$, et al. Population-based study of BRCA1 and BRCA2 mutations in 1035 unselected Finnish breast cancer patients. J Natl Cancer Inst. 2000,92:1529-31.

136. Sarantaus $L$, Auranen $A$, Nevanlinna H. BRCA1 and BRCA2 mutations among Finnish ovarian carcinoma families. Int J Oncol. 2001,18:831-5

137. Eerola H, Pukkala E, Pyrhonen S, Blomqvist C, Sankila R, Nevanlinna H. Risk of cancer in BRCA1 and BRCA2 mutation positive and negative breast cancer families (Finland). Cancer Causes Control. 2001,12:739-46.

138. Hartmann C, John AL, Klaes R, Hofmann W, Bielen R, Koehler R, et al. Large BRCA1 gene deletions are found in 3\% of German high-risk breast cancer families. Hum Mutat. 2004,24:534.

139. Engert S, Wappenschmidt B, Betz B, Kast K, Kutsche M, Hellebrand H. MLPA screening in the BRCA1 gene from 1506 German hereditary breast cancer cases: novel deletions, frequent involvement of exon 17, and occurrence in single early-onset cases. Hum Mutat. 2008;29:948-58

140. Meindl A. Comprehensive analysis of 989 patients with breast or ovarian cancer provides BRCA1 and BRCA2 mutation profiles and frequencies for the German population. Int J Cancer. 2002,97:472-80.

141. Anagnostopoulos T, Pertesi M, Konstantopoulou I, Armaou S, Kamakari S, Nasioulas G, et al. G1738R is a BRCA1 founder mutation in Greek breast/ovarian cancer patients: evaluation of its pathogenicity and inferences on its genealogical history. Breast Cancer Res Treat. 2008 Jul,110:377-85.
142. Koumpis C, Dimitrakakis C, Antsaklis A, Royer R, Zhang S, Narod SA, et al. Prevalence of BRCA1 and BRCA2 mutations in unselected breast cancer patients from Greece. Hered Cancer Clin Pract. 2011,9:10.

143. Van Der Looij M, Szabo C, Besznyak I, Liszka G, Csokay B, Pulay T, et al. Prevalence of founder BRCA1 and BRCA2 mutations among breast and ovarian cancer patients in Hungary. Int J Cancer. 2000,86:737-40.

144. Marroni F, Cipollini G, Peissel B, D'Andrea E, Pensabene M, Radice P, et al. Reconstructing the genealogy of a BRCA1 founder mutation by phylogenetic analysis. Ann Hum Genet. 2008,72:310-8.

145. Caligo MA, Ghimenti C, Cipollini G, Ricci S, Brunetti I, Marchetti V, et al. BRCA1 germline mutational spectrum in Italian families from Tuscany: a high frequency of novel mutations. Oncogene. 1996,13:1483-8.

146. MCDevitt TM. Spectrum and incidence of BRCA1 and BRCA2 mutations in the Republic of Ireland-An Audit (abstract). Eur J Hum Genet. 2009,17:195.

147. Tikhomirova L, Sinicka O, Smite D, Eglitis J, Hodgson SV, Stengrevics A. High prevalence of two BRCA1 mutations, 4154delA and 5382insC, in Latvia. Fam Cancer. 2005,4:77-84.

148. Janavicius R, Pepalyte I, Kucinskas V. Novel and common BRCA1 mutations in familial breast/ovarian cancer patients from Lithuania. Breast Cancer Res Treat. 2009;117:467-9.

149. Gronwald J, Elsakov P, Gorski B, Lubinski J. High incidence of 4153delA BRCA1 gene mutations in Lithuanian breast- and breast-ovarian cancer families. Breast Cancer Res Treat. 2005,94:111-3.

150. Borg A, Dorum A, Heimdal K, Maehle L, Hovig E, Moller P. BRCA7 1675 delA and 1135insA account for one third of Norwegian familial breast-ovarian cancer and are associated with later disease onset than less frequent mutations. Dis Markers. 1999,15:79-84.

151. Møller P, Hagen Al, Apold J, Maehle L, Clark N, Fiane B, et al. Genetic epidemiology of BRCA mutations--family history detects less than $50 \%$ of the mutation carriers. Eur J Cancer. 2007,43:1713-7.

152. Górski B, Jakubowska A, Huzarski T, Byrski T, Gronwald J, Grzybowska $\mathrm{E}$, et al. A high proportion of founder BRCA1 mutations in Polish breast cancer families. Int J Cancer. 2004,110:683-6.

153. Sokolenko AP, Mitiushkina NV, Buslov KG, Bit-Sava EM, lyevleva AG, Chekmariova EV, et al. High frequency of BRCA1 5382insC mutation in Russian breast cancer patients. Eur J Cancer. 2006,42:1380-4.

154. Einbeigi Z, Bergman A, Meis-Kindblom JM, Flodin A, Bjursell C, Martinsson $T$, et al. Occurrence of both breast and ovarian cancer in a woman is a marker for the BRCA gene mutations: a population-based study from western Sweden. Fam Cancer. 2007,6:35-41.

155. Scottish/Northern Irish BRCA1/BRCA2 Consortium. BRCA1 and BRCA2 mutations in Scotland and Northern Ireland. Br J Cancer. 2003,88:1256-62.

156. Krajc M, Teugels E, Zgajnar J, Goelen G, Besic N, Novakovic S, et al. Five recurrent $B R C A 1 / 2$ mutations are responsible for cancer predisposition in the majority of Slovenian breast cancer families. BMC Med Genet. 2008,9:83.

157. Besic N, Cernivc B, de Greve J, Lokar K, Krajc M, Novakovic S, et al. BRCA2 gene mutations in Slovenian male breast cancer patients. Genet Test. 2008,12:203-9.

158. Krajc M, De Greve J, Goelen G, Teugels E. BRCA2 founder mutation in Slovenian breast cancer families. Eur J Hum Genet. 2002,10:879-82.

159. Díez O, Osorio A, Durán M, Martinez-Ferrandis Jl, de la Hoya M, Salazar $\mathrm{R}$, et al. Analysis of BRCA1 and BRCA2 genes in Spanish breast/ovarian cancer patients: a high proportion of mutations unique to Spain and evidence of founder effects. Hum Mutat. 2003,22:301-12.

160. Vega A, Campos B, Bressac-De-Paillerets B, Bond PM, Janin N, Douglas $F S$, et al. The R71G BRCA1 is a founder Spanish mutation and leads to aberrant splicing of the transcript. Hum Mutat. 2001,17:520-1.

161. Campos B, Díez O, Odefrey F, Domènech M, Moncoutier V, MartínezFerrandis Jl, et al. Haplotype analysis of the BRCA2 9254delATCAT recurrent mutation in breast/ovarian cancer families from Spain. Hum Mutat. 2003,21:452.

162. Johannsson O, Ostermeyer EA, Håkansson S, Friedman LS, Johansson $\mathrm{U}$, Sellberg $\mathrm{G}$, et al. Founding BRCA1 mutations in hereditary breast and ovarian cancer in southern Sweden. Am J Hum Genet. 1996,58:441-50.

163. Johannsson O, Ranstam J, Borg A, Olsson H. BRCA1 mutations and survival in women with ovarian cancer. N Engl J Med. 1997,336:1255-6. Author reply 1256-7. 
164. Einbeigi Z, Meis-Kindblom JM, Kindblom LG, Wallgren A, Karlsson P. Clustering of individuals with both breast and ovarian cancer a possible indicator of BRCA founder mutations. Acta Oncol. 2002;41:153-7.

165. Kremeyer B, Soller M, Lagerstedt K, Maguire P, Mazoyer S, Nordling M, et al. The BRCA1 exon 13 duplication in the Swedish population. Fam Cancer. 2005;4:191-4.

166. Einbeigi Z, Enerback C, Wallgren A, Nordling M, Karlsson P. BRCA1 gene mutations may explain more than $80 \%$ of excess number of ovarian cancer cases after breast cancer a population based study from the Western Sweden Health Care region. Acta Oncol. 2010,49:361-7.

167. Forbes C, Fayter D, de Kock S, Quek RG. A systematic review of international guidelines and recommendations for the genetic screening, diagnosis, genetic counseling, and treatment of BRCA-mutated breast cancer. Cancer Manag Res. 2019,11:2321-2337.

168. Alvarez C, Tapia T, Perez-Moreno E, Gajardo-Meneses P, Ruiz C, Rios M, et al. BRCA1 and BRCA2 founder mutations account for $78 \%$ of germline carriers among hereditary breast cancer families in Chile. Oncotarget. 20178:74233-74243

169. Łukomska A, Menkiszak J, Gronwald J, Tomiczek-Szwiec J, Szwiec M, Jasiówka M, et al. Recurrent mutations in BRCA1, BRCA2, RAD51C, PALB2 and CHEK2 in Polish patients with ovarian cancer. Cancers (Basel). 2021,13:849.

170. Jiang Y, Tian T, Yu C, Zhou W, Yang J, Wang Y, et al. Identification of recurrent variants in BRCA1 and BRCA2 across multiple cancers in the Chinese population. Biomed Res Int. 2020,15:6739823.

171. Gomaa Mogahed SH, Hamed YS, Ibrahim Moursy YE, Mahomoud Saied $\mathrm{MH}$. Analysis of heterozygous BRCA1 5382ins founder mutation in a cohort of Egyptian breast cancer female patients using pyrosequencing technique. Asian Pac J Cancer Prev. 2020,21:431-438.

172. Kwong A, Shin VY, Ma ES, Chan CT, Ford JM, Kurian AW, et al. Screening for founder and recurrent BRCA mutations in Hong Kong and US Chinese populations. Hong Kong Med J. 2018,24:4-6.

173. Laraqui $A$, Cavaillé $M$, Uhrhammer N, ElBiad O, Bidet $Y$, El Rhaffouli H,et al. Identification of a novel pathogenic variant in PALB2 and BARDI genes by a multigene sequencing panel in triple negative breast cancer in Morocco. J Genomics 2021,9:43-54

174. Bono M, Fanale D, Incorvaia L, Cancelliere D, Fiorino A, Calò V, et al. Impact of deleterious variants in other genes beyond BRCA1/2 detected in breast/ovarian and pancreatic cancer patients by NGSbased multi-gene panel testing: looking over the hedge. ESMO Open. 2021,6:100235.

175. Fanale D, Incorvaia L, Filorizzo C, Bono M, Fiorino A, Calò V, et al. Detection of Germline Mutations in a Cohort of 139 Patients with Bilateral Breast Cancer by Multi-Gene Panel Testing: Impact of Pathogenic Variants in Other Genes beyond BRCA1/2. Cancers (Basel). 2020,12:2415.

176. Besic N, Blatnik A, Nizic-Kos T, Novakovic S, Krajc M. Characteristics of breast cancer in Slovenian patients with germline CHEK2 c.444+1G >A mutation. JCO 38, no. 15_suppl

177. Pelttari LM, Shimelis H, Toiminen H, Kvist A, Törngren T, Borg A, et al. Gene-panel testing of breast and ovarian cancer patients identifies a recurrent RAD51C duplication. Clin Genet 2018,93:595-602.

178. Southey MC, Teo ZL, Dowty JG, Odefrey FA, Park DJ, Tischkowitz M, et al. A PALB2 mutation associated with high risk of breast cancer. Breast Cancer Res. 2010,12:R109.

179. Kluska A, Balabas A, Piatkowska M, Czarny K, Paczkowska K, Nowakowska D, et al. PALB2 mutations in BRCA1/2-mutation negative breast and ovarian cancer patients from Poland. BMC Med Genomics. 2017,10:14

180. Heikkinen T, Kärkkäinen H, Aaltonen K, Milne RL, Heikkilä P, Aittomäki $\mathrm{K}$, et al. The breast cancer susceptibility mutation PALB2 1592delT is associated with an aggressive tumor phenotype. Clin Cancer Res. 2009,15:3214-22.

181. Oosthuizen J, Kotze MJ, Van Der Merwe N, Myburgh EJ, Bester P, van der Merwe NC. Globally Rare BRCA2 Variants With Founder Haplotypes in the South African Population: Implications for Point-of-Care Testing Based on a Single-Institution BRCA1/2 Next-Generation Sequencing Study. Front Oncol. 2021,12:619469.

\section{Publisher's Note}

Springer Nature remains neutral with regard to jurisdictional claims in published maps and institutional affiliations.
Ready to submit your research? Choose BMC and benefit from:

- fast, convenient online submission

- thorough peer review by experienced researchers in your field

- rapid publication on acceptance

- support for research data, including large and complex data types

- gold Open Access which fosters wider collaboration and increased citations

- maximum visibility for your research: over $100 \mathrm{M}$ website views per year

At BMC, research is always in progress.

Learn more biomedcentral.com/submissions 